\title{
Forest Fires Across Italian Regions and Implications for Climate Change: A Panel Data Analysis
}

\author{
Melania Michetti ${ }^{1} \cdot$ Mehmet $\operatorname{Pinar}^{2}$ (ID \\ Accepted: 9 August 2018 / Published online: 23 August 2018 \\ (c) The Author(s) 2018
}

\begin{abstract}
In this paper, we analyze the determinants of monthly variations in forest fire frequency and on the size of the area burnt for Italian regions between 2000 and 2011. We employ panel data techniques, which allow capturing the dynamics of fire danger due to changes in past climatic conditions, after accounting for regional fixed effects to control region-specific unobserved and time-invariant factors. Results highlight a significant heterogeneity of the effects of driving factors across the Italian peninsula and weather seasons. Climatic conditions also show lasting effects within the year. Using climate change projections for 2016-2035, we then obtain the projected forest fire frequency and total area burnt across the Italian peninsula for the same period. Climate change is expected to increase the number of forest fires across the whole peninsula, which is more evident for the central part of Italy. Even though most of annual increases in fire events relate to the summer period, intensifications in frequency during autumn become more evident in the southern Italy. We extend finally our analysis to investigate the contribution of socio-economic factors to fire regime and the role of education and the containment of fraudulent activity is also highlighted.
\end{abstract}

Keywords Forest fires $\cdot$ Forestry $\cdot$ Climate change $\cdot$ Panel-data estimation

JEL Classification C33 · Q23 · Q54

\section{Introduction}

Forestland and trees offer vital services such as commercial and recreational uses, water and climate regulation services, and carbon sequestration activity. However, several forest disturbances undermine these service provisions. Compared to other factors (e.g., pests,

Mehmet Pinar

mehmet.pinar@edgehill.ac.uk

Melania Michetti

melania.michetti@cmcc.it

1 Centro Euro-mediterraneo sui Cambiamenti Climatici (CMCC), Via Aldo Moro 44, 40127 Bologna, Italy

2 Business School, Edge Hill University, St Helens Road, Ormskirk L39 4QP, UK 
plant diseases, wind, and frost), fire often represents the most threatening disturbance for forestland and trees in the southern Europe and Mediterranean area [Pausas et al. (2008) for Mediterranean area; Miranda et al. (2008) for Southern Europe; Dimitrakopoulos et al. (2011) and Koutsias et al. (2013) for Greece; Costa et al. (2011) for Portugal]. Italy is not an exception being affected by relevant fire risk where it lists as the fourth country for importance on fire events in the Mediterranean area, after Portugal, Spain, and France (San-Miguel-Ayanz et al. 2017).

Through the whole Italian peninsula, 7077 fire events were registered on average each year between 2000 and 2011 with around 76,350 hectare (ha) of area burnt annually on average. Forest fires in 2017 have been recorded as one of the worst one during the last 30 years for Italy as vast fire occurrences have taken place during summer, adding to the already important events in autumn. Ironically, in the same year, the National Italian Institute for Statistics (ISTAT) stopped recording official data on forest sector statistics. Furthermore, in 2017, the role of the Italian police force under civil law (Corpo Forestale dello Stato: CFS) on forest management, a department that works under the Ministry of Agricultural, Food and Forestry Policies Forest State Body of the Forestry Department, was reduced as a consequence of the Madia law (ddl Madia: 7/8/2015, n.124). This body was in charge of the recording of all fire events in the Italian peninsula; a task which is now taken over by a supranational institution (i.e., the Emergency Management Service of the European Forest Fire Information System). However, this supranational institution will only record large-scale fires (i.e., fires that results an area burnt over 30 ha), making the overall fire monitoring very hard. On the other hand, the causes of forest fires in Italy go beyond the contingency of this situation and are linked to the governance system and to the institutional arrangements in the management of forest resources, amongst other causes.

There are key factors that explain the fire regime (intended as the frequency and intensity — area burnt — of the wildfire prevailing in an area over certain periods of time) and risk such as the region-specific factors (e.g., Martinez et al. 2009; Westerling et al. 2006, among others). For instance, institutional arrangements to manage forest resources may vary across different regions due to available resources to fight forest fires. Recent studies also highlight that the value of forest ecosystems vary across regions, which requires different territorial forest management programs (see e.g., Rodríguez y Silva et al. 2012). On the other hand, some regions may have more of drier, mature, and dead materials, which is therefore more flammable compared to other regions (e.g., Blasi et al. 2005; Bernetti 2005). In the same lines, different forest types may be more prone to fires and could be clustered more in certain regions making those regions more exposed to fire danger (see e.g., Fernandes et al. 2010). In short, there are certain regional characteristics that differ from one another, which may lead to higher exposure of some regions to forest fires than others. In this paper, we use panel-data estimation techniques to control for these region-specific factors in our analysis.

A second group of factors that are found to be important for forest fires is the socioeconomic conditions and human attitudes. For instance, due to increased human pressure on forests, most populated or active areas (such as the areas that have higher levels of tourism) are found to be more prone to forest fires (Catry et al. 2007; Martinez et al. 2009). Similarly, regions that have economic hardship (e.g., regions with high poverty or unemployment) are also associated with higher levels of forest fires (see e.g., Prestemon and Butry 2005; Torres Curth et al. 2012), which may be due to lower resources available to monitor forests. On the other hand, agriculture activities and land management to renovate livestock pastures also play an important role in forest fire ignition risk (see e.g., Moreira et al. 2009). Over the last years, the relevance of socio-economic factors and human pressure has been identified by 
the literature (see e.g., Ganteaume et al. 2013 for a review of socio-economic factors that are found to be important for fire ignition risk), which will be also examined in this paper.

Finally, physical and weather elements are undeniably recognized as major determinants of the exposure to fire risk and spread of fire (Pausas 2004; Westerling et al. 2006; Pausas and Bradstock 2007; Pausas and Fernández-Muñoz 2012; Pausas and Paula 2012; Koutsias et al. 2013; Rego and Silva 2014; Salis et al. 2014). Increase in temperature levels and decrease in rainfall leads to higher drought levels making forests more flammable [see e.g., Vasilakos et al. (2009) for rainfall's contribution, Littell et al. (2016) for relevance of drought for ignition risk] where Koutsias et al. (2012) highlight the interaction between fuel accumulation and weather patterns.

Understanding the effects of region-specific, socio-economic and weather elements on forest fire is essential to prepare for climate change impacts on future forest fire. Researchers have been traditionally utilizing fire indicators, such as the Canadian fire weather index (FWI), ${ }^{1}$ which considers the daily accumulated precipitation and instantaneous wind speed, humidity, and temperature (see e.g., Van Wagner and Pickett 1987; Bedia et al. 2013; Jolly et al. 2015; Bedia et al. 2015), neglecting, however, the consideration of socio-economic factors. In this paper, rather than investigating fire indices based on fire-specific factors, we examine the contributions of weather factors at first, and socio-economic conditions in a later step, on the monthly and yearly variation in forest fire regime in Italy, respectively. After investigating historical data and fire relations, the analysis is extended to project the impact of future climate change on forest fire.

This paper contributes to the literature in several different ways. First, in addition to consider geographical clusters (i.e., spatial grouping), it extends the analysis to the overall Italian peninsula, while most of existing studies for Italy only focus on regional fire events. ${ }^{2}$ Secondly, previous studies normally do not account for time-invariant region specific factors and time-effects in their analysis, which could lead to omitted variable bias. Most are based on the observation of the simple historical trends and do not apply accurate statistical techniques to corroborate obtained results. Additionally, geographical-oriented approaches to forest fire analysis tend to consider fire realizations at some point in time (e.g., one specific year), neglecting fire temporal dynamics. This work, on the other hand, fully captures the dynamics of fire occurrence and the variations in weather conditions in time. By using panel-data estimation techniques we are able to account for time-invariant region-specific factors and time-effects, which are often omitted in the estimations. Time-invariant heterogeneity is represented by all those unobservable but relevant components characterizing a region, which are expected to be correlated with observed factors. Examples of region-specific factors are land and forest management, forest and fuel types, cultural values, regional and organizational culture, and land use among many other factors that can affect forest fire dynamics. While this instance represents a persistent problem in cross-sectional analysis, using panel data estimation techniques allows us to control for the regional heterogeneity. Finally, while very few studies evaluated the influence of socioeconomic conditions on the occurrence of forest fires, we also extended our analysis in this direction.

The paper is organized as follows. Section 2 briefly reviews the methodologies used to examine fire events and intensities and offers details on the proposed methodology. Sec-

\footnotetext{
${ }^{1}$ FWI represents an estimation of the risk of wildfire based on the assumption that fire occurrence mainly depends on moisture content of litter and other fine fuels. Its computation requires considering meteorological parameters such as air temperature, relative humidity, wind speed, and precipitation.

2 Examples of regional analyses are provided by Telesca and Lasaponara (2006) for central Italy; Bajocco and Ricotta (2008), Telesca et al. (2005) and Pazienza and Beraldo (2004) for southern Italy; Zumbrunnen et al. (2009) and Wastl et al. (2012) for northern Italy.
} 
tion 3 summarizes the fire, weather and socio-economic data. Relationships between monthly forest fire frequency (area burnt) and weather variables for different geographical clusters are presented in Sect. 4. Section 4 also provides an estimation of the impact of projected changes in temperature and precipitation on forest fire frequency and total area burnt for different geographical clusters in Italy during 2016-2035. Section 5 concludes discussing policy implications.

\section{Brief Review of Methodologies and Estimation Method}

Several methodologies have been used within the existing literature to explain the main factors of fire risk. The choice of methodology strictly depends on the objective of the study, which can either be that of predicting future fire incidences or explaining the variation of the dependent variable. The choice of the methodology may also depend on the characteristics of the dependent variable, which can be discrete, dichotomous (when it only takes the values of 0 and 1 ), or continuous.

While several analyses implement stepwise-multiple linear regressions (i.e., multivariate ordinary least squares) when the dependent variable is continuous (e.g., Vadrevu et al. 2006), one of the most frequently implemented techniques within fire risk analysis is the binary response regressions (see e.g., Martinez et al. (2009) for the use logistic regression, and Wotton et al. (2003) for the use of Poisson regression). The application of binary regressions does not prevent the researcher from incurring into problems of bias and inconsistency of the estimates, if unobserved heterogeneity across regions/areas is not accounted in the analysis (Baltagi 2008). The spatial heterogeneity might rise due to a lack of structural stability or homogeneity of unit observation across space. Supposedly, Italian regions are heterogeneous in terms of cultural differences (Naveh 1995), land cover types (Bajocco and Ricotta 2008), law enforcement mechanisms, and the power and participation of local organizations to public life and economy. When this is the case, the fixed or random effects models should be used in the presence of panel data (Kousky and Olmstead 2010; Reetz and Brummer 2011). While there is a variety of cross sectional analyses investigating forest fire events, according to our knowledge, there are very few articles providing a panel data specification. Although Vadrevu et al. (2006) attempted to head towards this direction, they do not fully exploit the advantages of a panel data approach as they analyze yearly data in a cross-sectional fashion. More recently, Hargrave and Kis-Katos (2013) employed panel data techniques to analyze how time-varying factors, such as increasing economic and agricultural activities, affected deforestation in the Brazilian Amazon.

On the same path, we propose a panel data approach to investigate the influence of weather and socio-economic conditions on fire occurrence and area burnt in Italian peninsula during the last decade, while accounting for the unobserved heterogeneity across regions. Fixed effects estimations are performed by adding region and time dummies to the regressions (Prestemon et al. 2002; Preisler et al. 2004). Regional effects may capture different forest covers, land management, culture, and law enforcement across the regions. On the other hand, year effects can capture a policy shift that influenced all of the regions at a given time.

Assuming $N$ regions $(i=1,2, \ldots, \mathrm{N})$ and $\mathrm{T}$ periods of time $(t=1,2, \ldots, \mathrm{T})$, the standard representation of the fixed effect panel estimation method takes the following form:

$$
y_{i t}=\alpha_{i}+\gamma_{t}+X_{i t}^{\prime} \beta+\varepsilon_{i t}
$$


where $y_{i t}$ is the dependent variable (either the natural logarithm of the total number of fire events, or the natural logarithm of the total area burnt in hectares in a given region (i), in a given time (t)). $\alpha_{i}$ is the region dummy variable for regional fixed effects; $\gamma_{t}$ is a year dummy variable which controls for time varying common shocks; vector of $X_{i t}$ includes the set of explanatory variables for a given region (i), in a given time (t) which are the weather and socio-economic variables depending on the empirical exercise; and $\varepsilon_{i t}$ is the standard white noise error term.

With noticing is that if $\alpha_{i}$ is correlated with any of the time-varying explanatory variable, regressing the dependent variable (i.e., forest fire events) on explanatory variables will lead to bias in the estimations. As a result, ordinary least squares (OLS) estimates would be biased coefficients and lead to invalid standard errors (Baltagi 2008). Hence, in this paper, we use fixed effects methodology where we control for region-specific time-invariant factors and time effects, which allows us to obtain unbiased coefficients and robust standard errors.

Throughout the empirical analysis section, we use the estimation technique proposed in Eq. (1), however, the set of explanatory variables used in the empirical analysis were different depending on their availability. In particular, using (1), we first investigate the relationships between monthly weather conditions (i.e., monthly precipitation (millimetre) and temperature $\left({ }^{\circ} \mathrm{C}\right)$ levels) and monthly total forest fire events (area burnt) across the Italian regions. In this exercise, we first consider the monthly data simultaneously (without differentiating between different seasons) to examine the effects of precipitation and temperature on forest fire events and area burnt (see Sect. 4.1). Then, we considered the effects of monthly weather conditions on forest fires events and area burnt for each month separately during January 2000 and December 2011 (see Sects. 4.2 and 4.3) where we find that the effect of weather conditions vary across months and space. Given this heterogeneity of the effects, we use the estimates obtained in Sects. 4.2 and 4.3 to predict forest fire regime under future climate (Sect. 4.4). To this aim, we employ projections on surface temperature $\left({ }^{\circ} \mathrm{C}\right)$ and precipitation $(\%)$ levels reported in the IPCC 5th Assessment Report (IPCC 2013) for different geographical clusters in Italy. Finally, we use the estimation technique proposed in Eq. (1) to assess the relation between fire regime and socio-economic factors, organizing data in a yearly fashion for both dependent and independent variables given that most of time-variant socio-economic variables are only available on yearly basis.

\subsection{Method for Choosing Climate Change Projections}

Climate change projections for Italy are derived from European-scale projections resulting from the ENSEMBLES project (http://ensembles-eu.metoffice.com/), which uses regional climate models (RCMs) driven by global climate models (GCMs). The underlying socioeconomic scenario, governing the future amount of greenhouse gas concentration in the atmosphere leading to the assumed values of precipitation and temperature, is the A1B of the IPCC Special Report on Emissions Scenarios (SRES) (Morita et al. 2001). ${ }^{3}$

Projections provided for summer (June, July, and August (JJA) hereafter) and winter (December, January, and February (DJF) hereafter) are derived from major climate models developed around the world and are expressed in climate anomalies. Climate anomalies are

\footnotetext{
3 The A1B scenario belongs to the A1 family assuming very rapid economic growth in the future and driven by a rapid introduction of new and more efficient technologies. This scenario also assumes that global population peaks in mid-century and declines thereafter. A major issue in this scenario is the convergence among regions, capacity building, and increased cultural and social interactions, which support the reduction of differences in per capita income across regions. The A1B, in addition, is characterized by balanced progress across all resources (including land use and energy) and technologies.
} 
Table 1 Climate change projections for temperature $\left({ }^{\circ} \mathrm{C}\right)$ and precipitation $(\%)$ applied to north, centre, and south of Italy in winter and summer periods. Source: Own elaboration from IPCC (2013)

\begin{tabular}{|c|c|c|c|c|c|c|}
\hline \multirow{2}{*}{$\begin{array}{l}\text { Geographic } \\
\text { cluster }\end{array}$} & \multicolumn{3}{|c|}{ Temperature } & \multicolumn{3}{|c|}{ Precipitation } \\
\hline & $\operatorname{Min}\left({ }^{\circ} \mathrm{C}\right)$ & $\operatorname{Max}\left({ }^{\circ} \mathrm{C}\right)$ & Mean $\left({ }^{\circ} \mathrm{C}\right)$ & $\operatorname{Min}(\%)$ & $\operatorname{Max}(\%)$ & Mean $(\%)$ \\
\hline \multicolumn{7}{|c|}{ Summer projections (JJA) } \\
\hline North & 0.90 & 1.20 & 1.05 & +5 & +10 & +7.5 \\
\hline Centre & 1.20 & 1.50 & 1.35 & 0 & -5 & -2.5 \\
\hline South & 0.90 & 1.20 & 1.05 & 0 & -5 & -2.5 \\
\hline \multicolumn{7}{|c|}{ Winter projections (DJF) } \\
\hline North & 0.90 & 1.20 & 1.05 & -5 & -10 & -7.5 \\
\hline Centre & 0.90 & 1.20 & 1.05 & 0 & -5 & -2.5 \\
\hline South & 0.30 & 0.60 & 0.45 & -5 & -10 & -7.5 \\
\hline
\end{tabular}

obtained by differencing future climate conditions, 2016-2035 climate conditions, from the present ones, 1986-2005 climate conditions. ${ }^{4}$ Given that each model provides a different projection, it is common use to consider the multi-model ensemble-mean anomalies as they will always outperform most of the ensemble members.

Table 1 provides the minimum and maximum possible changes in temperature and precipitation for the summer (i.e., JJA) and winter (i.e., DJF) periods for three geographic clusters (i.e., north, center, and south of Italy). ${ }^{5}$ To remain within a conservative climate scenario, we compiled the average of these extreme cases (i.e., average of the minimum and maximum projections), and use the values reported in columns titled "mean" for the forest fire projections for the summer (JJA) and winter (DJF) periods.

For those months for which we did not have information on climate projections, i.e., March, April, and May (MAM hereafter) and September, October, and November (SON hereafter) we simulated two different scenarios making assumptions on future climate for the spring (i.e., MAM) and autumn (i.e., SON) periods. For the first scenario (Scenario 1), after observing past monthly trends and realizing existing similitudes at month level, the mean temperature and precipitation projections for the JJA are used for May, September, and October months, while the DJF values are used for March, April, and November. In other words, we use the mean temperature and precipitation projections for the JJA for the months between May and October, and the mean temperature and precipitation projections for the DJF for the period between November and April. For the second climate scenario (Scenario 2), average temperature and precipitation projections of JJA and DJF are used both for the spring (MAM) and autumn (SON) periods. The use of two scenarios allows us to perform a sensitivity analysis of climate change projections. Table 2 summarizes the final temperature and precipitation projections used for different time periods and geographical clusters of

\footnotetext{
4 Simulations used relate to the following models: HadRM3Q0-HadCM3Q0, ETHZ-HadCM3Q0, HadRM3Q3-HadCM3Q3, SMHI-HadCM3Q3, HadRM3Q16-HadCM3Q16, SMHIBCM, DMI-ARPEGE, KNMI-ECHAM5, MPI-ECHAM5, DMI-ECHAM5 (for further details see IPCC 2013).

5 The distribution of fire data indicates that we should use two geographical clusters for the central Italy (i.e., central-north and central-south of Italy) in our analysis (see next section for details). Hence, for central-north and central-south clusters we use the climate change projections for central Italy since climate projections for the central Italy is not distinguished in two clusters.
} 


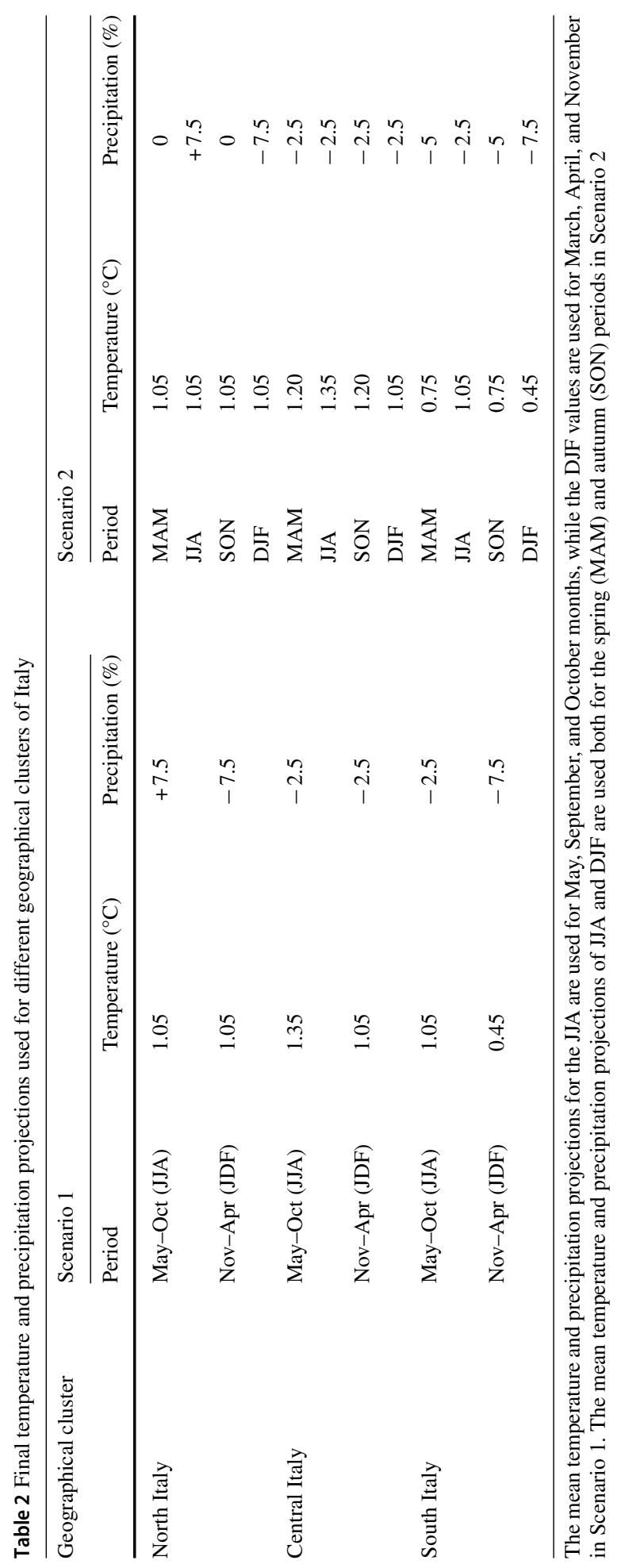


Italy. All the figures for temperature and precipitation have been firstly calculated for each month, as described above, and then used for each month.

In Sect. 4, we will examine the relationship between average temperature and precipitation with the total events (area burnt) over a given period. Hence, in order to obtain forest fire events (area burnt) projections, we need to obtain unit changes in temperature and precipitation with the climate change anomalies. However, climate change projections for precipitation are only available in percentage values (see Tables 1 and 2). To obtain unit changes in precipitation in each month with the climate change, we applied the percentage changes to the average precipitation levels in each month between 2000 and 2005 for north, centre, and south of Italy in order to obtain unit change in precipitation for each month between 2016 and $2035 .{ }^{6} \mathrm{We}$ used the averages across 2000-2005 since values relative to the period 1986-2005 were not at our disposal for the geographic detail of our analysis. This is the closest period for which we have information about precipitation levels for all months across Italian regions. This approach can be applied as Italian climatology in 1986-2005 has been always characterized by specific elements that can be still captured also considering only 2000-2005 period. Meteorological events present a phenomenology that depends essentially on stable factors such as the orographic relief, the distance from the sea or from large reservoirs and the soil type determine local systematic variations of the meteorological signal (Esposito et al. 2015). Therefore, they are captured independently on the period on which the climatic averages are calculated. Overall, this final step allowed us to project unit changes in precipitation and temperature levels in each month with the climate change projections for all Italian regions, which will be then used to obtain forest fire event and area burnt projections.

\section{Data Set and Statistics of Major Variables}

From the data collection on both dependent, socio-economic factors, and climatic variables, we worked to reach a balanced data set (i.e., a set that contains all elements observed in all time frame for all regions of Italy), including information about fire events/area burnt (Sect. 3.1), precipitation/temperature levels (Sect. 3.2), and socio-economic conditions (Sect. 3.3) for 19 regions. ${ }^{7}$ Fire and weather information was collected for all months between 2000 and 2011, while socio-economic factors are available on yearly basis.

\subsection{Fire Across Time and Space and Data Organization in Geographical Clusters}

The European Forest Fire Information System (EFFIS) of the European Commission Joint Research (CJR) Centre and the State Forestry Department of Italy (i.e., Corpo Forestale dello Stato) record monthly data which were used for the construction of two different dependent variables for all regions of Italy, covering the period between 2000 and 2011. The first dependent variable is the total number of fire events in each region at a given month. The second one is the total area burnt (in hectares) in each region at a given month. The two variables are highly and positively correlated across Italian regions but capture different

\footnotetext{
6 For instance, if average precipitation in June is $X$ millimetre (mm) for north of Italy between 2000 and 2005 , unit change in precipitation for the north of Italy with the climate change projections will be $0.075 \mathrm{X} \mathrm{mm}$ since the precipitation in June will be increased by $7.5 \%$ in June at north Italy.

7 We eliminated Valle D'Aosta region from our analysis due to lack of data on most of the socio-economic and climatic variables. This region is the least prone area to forest fires in Italy (i.e., on average, Valle D'Aosta had 15 fire events resulting 89 hectares of area burnt per year between 2000 and 2011) and we believe that its exclusion has no major impact on findings of this paper.
} 


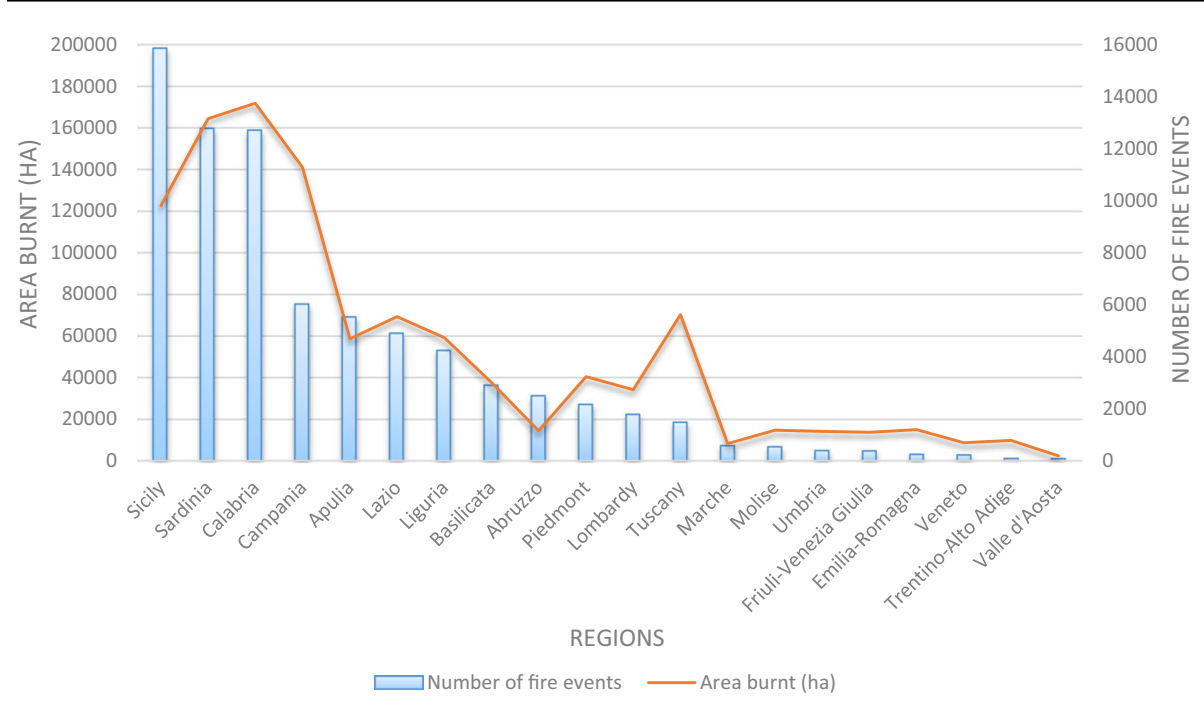

Fig. 1 Total number of fire events and area burnt between 2000 and 2011 across Italian regions

aspects of fire dynamics. ${ }^{8}$ Therefore, using them both allows drawing important evidence and a richer interpretation of the analysis.

Among the Mediterranean countries, Italy represents one of the most prone areas to forest fires. For example, Moriondo et al. (2006) find that Italy experiences the highest increase in annual climatic extreme events in future scenarios conducted through return period analysis. Analyzing distributions over time and space of fire events and area burnt for each region during 2000-2011, we confirm that fire events cover the entire Italian peninsula, from the north to the south. However higher frequency and larger fire events occur in the south (Fig. 1). ${ }^{9}$

In addition to taking different connotation from north to south, fire occurrence and total area burnt in Italy show variation across different months and regions. According to the statistical mode and geographical location of fire occurrence and area burnt, we can distinguish amongst four geographical clusters showing similar forest fire characteristics (i.e., north, central-north, central-south, and south of Italy). ${ }^{10}$ As we move from south to north, we switch from unimodal (south) to a mix between bimodal and unimodal distributions (central-south) and from bimodal (central-north) to plurimodal (north) distributions of fire occurrence (Fig. 2). The biggest incidence across space mainly relates to summer months, whereas the second pick in frequency is observed around March. This is likely the result of land management practices such as the use of fire by farmers and anglers to improve rangeland productivity and vegetation regeneration. Agricultural burning is a method commonly used by landowners and farmers to enhance soil fertilization, to prepare fields for harvest activity, and to dispose crop residues. However, despite this strategy traces back in time, Italians'

8 Correlation between total area burnt and the number of fire events for all regions over time is 0.74.

9 This explains why the few existing Italian-based analyses on fire events mostly focus on southern Italy (Pazienza and Beraldo 2004; Bajocco and Ricotta 2008).

${ }^{10}$ Regions listed in each geographical cluster are as follows. North: Piedmont, Lombardy, Liguria, TrentinoAlto Adige, Veneto, Friuli-Venezia Giulia, and Valle D’Aosta. Central-north: Emilia Romagna, Tuscany, Umbria, and Marche. Central-south: Lazio, Abruzzo, Molise, and Campania. South: Apulia, Basilicata, Sicily, Sardinia, and Calabria. 


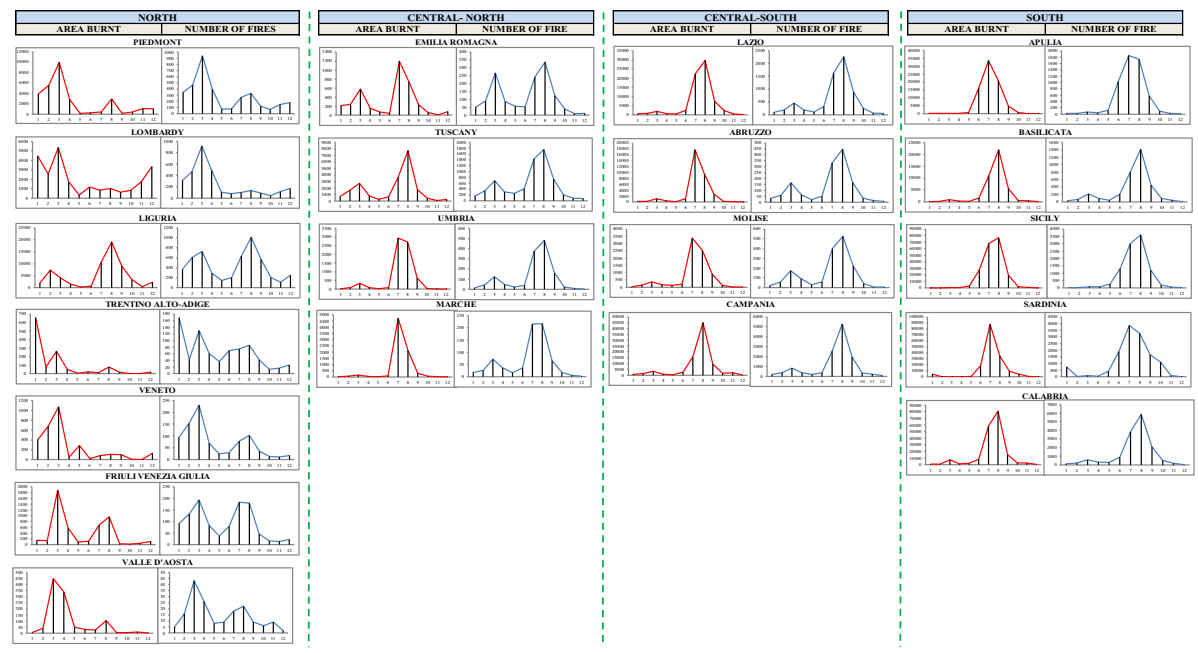

Fig. 2 Monthly average number of fire events and area burnt for different geographical clusters between 2000 and 2011

expertise in prescribed burning may be considered as a fire hazard-reduction (rather than hazard-increase) strategy (Ascoli and Bovio 2013). In addition, when the temperatures start increasing, fine vegetation or dead fuels lose moisture rapidly, forest becoming more prone to early season fires (March and April period). In the north and parts of the central-north, events take place both during summer and winter periods, and these areas are characterized by a continental climate of having no proper dry season. In addition, as alive and woody vegetation has slower moisture dynamics, fire susceptibility is reached only late in the summer season (i.e., events last until late summer).

\subsection{Weather Conditions Across Time and Space}

To understand the relationship between climatic factors and forest fire regime, we collected monthly averages of temperature and rainfall between 2000 and 2011 for each region, which are elaborated from the Italian Agriculture Research Council and the Research Unit for the Climatology and Meteorology for Agriculture. ${ }^{11}$ Despite inter-annual variability, specific monthly dynamics can be identified for precipitation levels across geographical clusters (see Fig. 3). Average precipitation levels increase during the winter period (i.e., between September and December) and lowers during the summer period (i.e., between May and August). However, average monthly precipitation varies across different geographical clusters where the precipitation levels are higher in the north than the south for almost all of the months. On the other hand, annual average of monthly temperatures also show a clear seasonal variation where average temperature progressively increases from January onwards and peaks in July (August for central south) to then decline (see Fig. 4). This seasonal variation in

\footnotetext{
11 The Italian Agriculture Research Council and the Research Unit for the Climatology and Meteorology for Agriculture are known as the Italian Consiglio per la Ricerca in Agricoltura and Unità per la Climatologia e la Meteorologia applicate all'agricoltura, which provide detailed climatic data for Italian regions. For more information visit at: http://cma.entecra.it/homePage.htm.
} 


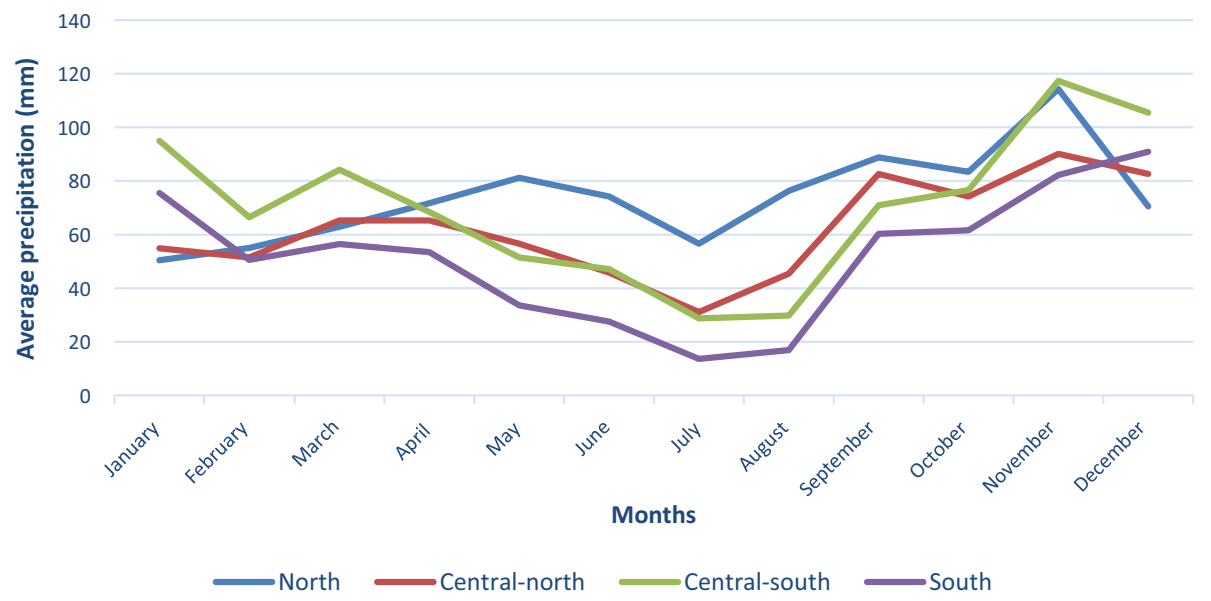

Fig. 3 Monthly mean precipitation levels across geographical areas (mm)

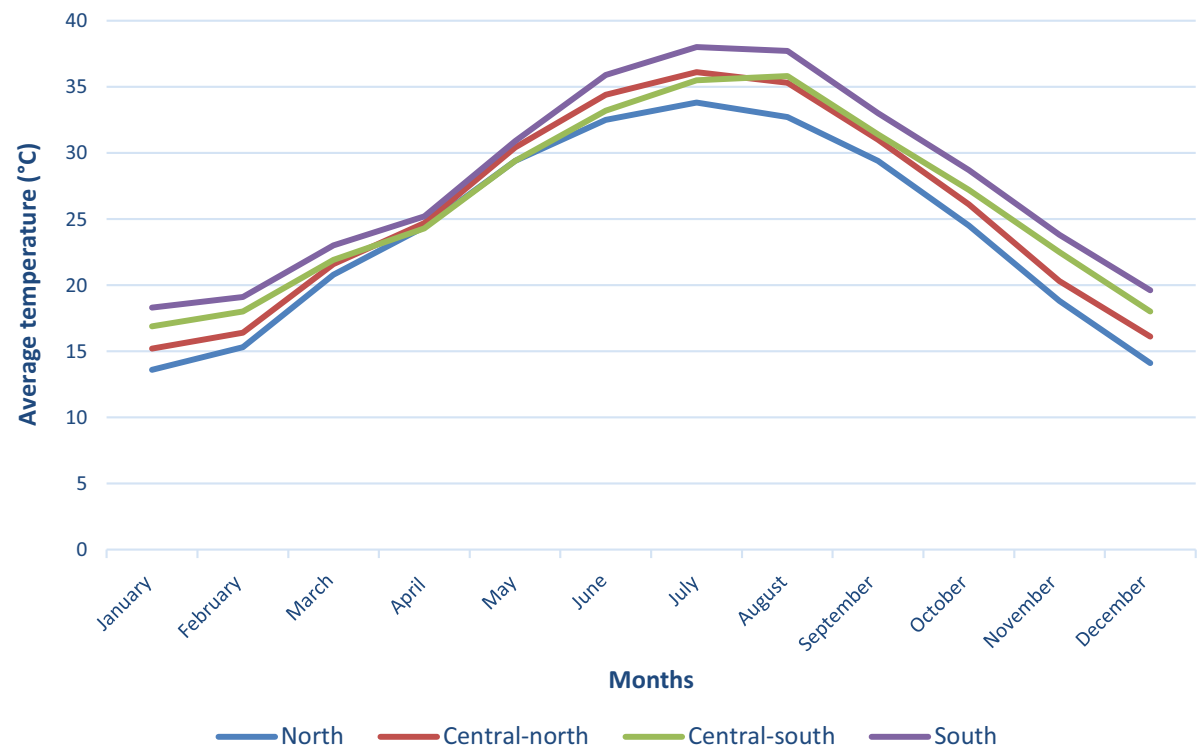

Fig. 4 Monthly mean temperature levels across geographical areas $\left({ }^{\circ} \mathrm{C}\right)$

precipitation and temperature has been accounted in the literature and found to be important factor explaining fire events (see e.g., Bajocco and Ricotta 2008), which will be also accounted in this paper. ${ }^{12}$

12 In this analysis, we do not control for the monthly wind speed since it has been noted that it does not provide any explanation to monthly variations in forest fires (see e.g., Lasslop et al. 2015 for a discussion on this). 


\subsection{Socio-economic Factors}

There exist several socio-economic factors that affect forest fire ignition probability and spread (see e.g., Ganteaume et al. 2013 for a comprehensive list of socio-economic driving factors of forest fire across Europe). Amongst others, we have made an effort to collect data on those factors that are more likely to affect the fire conditions in Italy. For example, differences in livestock density could explain, in some regions, an increase in the risk of fire occurrence due to maintenance of pastures (Lloret et al. 2002; Martinez et al. 2009). Furthermore, burning shrubland is a widespread practice in rural areas across the Mediterranean region to renovate livestock pastures (see e.g., Moreira et al. 2009). To capture these effects across regions and time, we use the natural logarithm of the total livestock units per kilometre square in a given region.

Similarly, the existence of agricultural activities may also affect the likelihood of forest fires. For instance, Ricotta et al. (2012) find that decreased human impact associated with agriculture land abandonment leads to a statistically significant decline in fire ignition probability in Sardinia. To capture the effect of the presence of agricultural activity across the regions, we use the percentage of employment in agriculture as a proxy. In the same lines, most populated or active areas (e.g., closeness of forests to the roads and railways) are found to be more prone to forest fires because of the increased human pressure (Catry et al. 2007; Martinez et al. 2009). This effect is accounted for by using the natural logarithms of population density (i.e., total population in a region divided by the total area in kilometre squares) and railway density (i.e., kilometres of regional railways divided by the total regional area in kilometre squares).

Finally, socio-economic well-being of a region may play a role in human induced and intentional forest fires. Especially in the past, forests have been voluntarily set on fire to create firefighting jobs or to gain land for agriculture and pasture, which were retained more valuable than logging (Leone et al. 2002). Indeed, low timber returns along with negligent forest management can result in higher fire risk (Gonzalez-Olabarria and Pukkala 2011). For instance, Prestemon and Butry (2005) found positive associations between poverty and unemployment rates with the arson ignition rates. However, de Torres Curth et al. (2012) found that the areas with fewer fires tend to be characterized by population with higher levels of education. To capture the effects of these socio-economic factors, we consider the variables of relative poverty (measured by the percentage of population in a given region that live under relative poverty line), education (measured by the percentage of the population aged between 25 and 64 with tertiary education attainment), and illegal activity (measured by the number of extortions per 100,000 inhabitants).

The complete list of the socio-economic factors considered is provided in Appendix Tables 10 where Table 3 offers the descriptive statistics for the indicators used in the regression analysis. It can be seen that socio-economic conditions show good variation across the regions and geographical clusters.

\section{Results}

\subsection{Weather Effects on Fire Events and Area Burnt}

In this subsection, we first investigate the relationship between monthly precipitation and temperature levels across time (i.e., between January 2000 and December 2011) and forest fire events or area burnt during the same period, after controlling for regional and time 
Table 3 Summary statistics of socio-economic variables

\begin{tabular}{|c|c|c|c|c|c|}
\hline Variable & Mean & SD & Minimum & Maximum & $\mathrm{N}$ \\
\hline \multicolumn{6}{|c|}{$\begin{array}{l}\text { Summary statistics for all the regions in Italian } \\
\text { peninsula }\end{array}$} \\
\hline ln Livestock intensity & 3.09 & 0.67 & 1.44 & 4.74 & 228 \\
\hline $\begin{array}{l}\text { Percentage of employment in } \\
\text { agriculture }\end{array}$ & 5.38 & 2.90 & 1.36 & 12.79 & 228 \\
\hline ln Population density & 5.06 & 0.57 & 4.05 & 6.04 & 228 \\
\hline ln Railway density & 1.19 & 0.40 & 0.53 & 2.18 & 228 \\
\hline Relative poverty & 12.78 & 8.59 & 2.50 & 30.80 & 228 \\
\hline Percentage of territory degree & 12.36 & 2.66 & 6.70 & 19.60 & 228 \\
\hline $\begin{array}{l}\text { Extortion per } 100,000 \\
\text { inhabitants }\end{array}$ & 8.52 & 3.98 & 2.25 & 21.44 & 228 \\
\hline \multicolumn{6}{|c|}{ Summary statistics for the regions in the northern Italy } \\
\hline ln Livestock intensity & 3.28 & 0.99 & 1.44 & 4.74 & 72 \\
\hline $\begin{array}{l}\text { Percentage of employment in } \\
\text { agriculture }\end{array}$ & 3.50 & 1.66 & 1.36 & 8.81 & 72 \\
\hline ln Population density & 5.27 & 0.55 & 4.22 & 6.00 & 72 \\
\hline ln Railway density & 1.13 & 0.32 & 0.53 & 1.47 & 72 \\
\hline Relative poverty & 5.60 & 1.70 & 3.30 & 9.90 & 72 \\
\hline Percentage of territory degree & 12.28 & 2.54 & 7.95 & 18.70 & 72 \\
\hline $\begin{array}{l}\text { Extortion per 100,000 } \\
\text { inhabitants }\end{array}$ & 5.90 & 2.09 & 2.25 & 10.48 & 72 \\
\hline \multicolumn{6}{|c|}{ Summary statistics for the regions in the central-north of Italy } \\
\hline ln Livestock intensity & 3.03 & 0.53 & 2.39 & 3.91 & 48 \\
\hline $\begin{array}{l}\text { Percentage of employment in } \\
\text { agriculture }\end{array}$ & 3.84 & 0.81 & 2.03 & 5.90 & 48 \\
\hline In Population density & 4.98 & 0.23 & 4.57 & 5.26 & 48 \\
\hline ln Railway density & 1.21 & 0.24 & 0.92 & 1.52 & 48 \\
\hline Relative poverty & 5.75 & 1.54 & 2.50 & 9.10 & 48 \\
\hline Percentage of territory degree & 13.54 & 2.22 & 9.40 & 17.20 & 48 \\
\hline $\begin{array}{l}\text { Extortion per } 100,000 \\
\text { inhabitants }\end{array}$ & 6.92 & 1.79 & 3.29 & 10.88 & 48 \\
\hline \multicolumn{6}{|c|}{ Summary statistics for the regions in the central-south of Italy } \\
\hline In Livestock intensity & 3.16 & 0.28 & 2.69 & 3.63 & 48 \\
\hline $\begin{array}{l}\text { Percentage of employment in } \\
\text { agriculture }\end{array}$ & 5.09 & 2.41 & 1.53 & 11.46 & 48 \\
\hline In Population density & 5.20 & 0.72 & 4.26 & 6.04 & 48 \\
\hline ln Railway density & 1.24 & 0.60 & 0.54 & 2.18 & 48 \\
\hline Relative poverty & 16.56 & 6.70 & 6.00 & 27.00 & 48 \\
\hline Percentage of territory degree & 13.37 & 3.07 & 8.70 & 19.60 & 48 \\
\hline $\begin{array}{l}\text { Extortion per } 100,000 \\
\text { inhabitants }\end{array}$ & 10.77 & 4.38 & 4.76 & 21.44 & 48 \\
\hline
\end{tabular}


Table 3 continued

\begin{tabular}{|c|c|c|c|c|c|}
\hline Variable & Mean & SD & Minimum & Maximum & $\mathrm{N}$ \\
\hline \multicolumn{6}{|c|}{ Summary statistics for the south regions of Italy } \\
\hline ln Livestock intensity & 2.86 & 0.40 & 2.31 & 3.61 & 60 \\
\hline $\begin{array}{l}\text { Percentage of employment in } \\
\text { agriculture }\end{array}$ & 9.10 & 1.91 & 4.98 & 12.79 & 60 \\
\hline In Population density & 4.75 & 0.53 & 4.05 & 5.33 & 60 \\
\hline In Railway density & 1.20 & 0.39 & 0.71 & 1.83 & 60 \\
\hline Relative poverty & 23.50 & 4.26 & 13.30 & 30.80 & 60 \\
\hline Percentage of territory degree & 10.69 & 1.79 & 6.70 & 14.00 & 60 \\
\hline $\begin{array}{l}\text { Extortion per } 100,000 \\
\text { inhabitants }\end{array}$ & 11.17 & 4.02 & 4.54 & 19.86 & 60 \\
\hline
\end{tabular}

fixed effects. In this case, we do not account for the potentially different effects of weather conditions on forest fires and total area burnt in different seasons and consider whole set of panel data simultaneously.

Tables 4 and 5 offer the relationships between monthly weather factors (temperature and precipitation) and monthly forest fire events and total area burnt for the whole Italian peninsula, north, central-north, central-south and south of Italy, respectively. Findings confirm a clear regional heterogeneity across space and time (except for southern Italy). Regional and time effects explain around $30 \%$ of the monthly variation in fire events in the north, centralnorth and central-south of Italy, as highlighted from the R-squares obtained when we use regional and time dummies only. Regional effects only explain $7 \%$ of the variation in forest fires in the south of Italy. To disentangle the additional effect of weather components (i.e., additional explanatory power), we introduce weather factors into the analysis after accounting for the regional and time fixed effects. Adding monthly weather data in time (t) and their lagged values, we observe that in all geographical clusters, with exception of the south, fire frequency (area burnt) in a given month $(\mathrm{t})$ is negatively associated with precipitation levels occurring in that month $(\mathrm{t})$ and in the two previous months $(\mathrm{t}-1$ and $\mathrm{t}-2)$. In the south, the effects of precipitation lasts one month rather than two months. For example, for the Italian case (i.e., the results that are presented in the first column of Table 4), an increase in average precipitation level by 10 millimetres in time $(\mathrm{t}),(\mathrm{t}-1)$, and $(\mathrm{t}-2)$ (i.e., precipitation levels in a given month and two previous months) corresponds to a decrease in fire frequency by $8.9 \%, 7.8 \%$, and $3.4 \%$, respectively. ${ }^{13}$

On the other hand, warmer temperatures in month (t) imply significantly higher fire frequency (area burnt) in the whole peninsula. Temperature shows lasting effects in the south of Italy, where higher temperature in previous month $(\mathrm{t}-1)$ increases fire frequency in month $(\mathrm{t})$. An increase of one degree Celsius in month $(\mathrm{t})$ and $(\mathrm{t}-1)$ corresponds, respectively, to a $15 \%$ and $3 \%$ increase in fire frequency in south of Italy. Whereas, a similar increase in temperature in month (t) leads to $0.9 \%, 5.7 \%, 5.5 \%$ increases in fire frequency in north, central-north and central-south of Italy, respectively.

Overall, both precipitation and temperature have lasting effects on fire frequency and total area burnt, although the effect declines as the weather realization becomes more distant in

\footnotetext{
13 Since the log-linear transformation is used in our regressions, we can obtain how a unit change in weather components correspond to a percentage change in the dependent variable by $\left[\left(\mathrm{e}^{\beta}-1\right) \times 100 \%\right]$, where $\beta$ is the coefficient for the weather component in interest.
} 
Table 4 Relationship between weather variables and fire events without differentiating for seasonal effects

\begin{tabular}{|c|c|c|c|c|c|}
\hline Variables & All regions & North & Central North & Central South & South \\
\hline Precipitation $(\mathrm{t})$ & $\begin{array}{l}-0.0093 * * * \\
(0.001)\end{array}$ & $\begin{array}{l}-0.0077 * * * \\
(0.001)\end{array}$ & $\begin{array}{l}-0.0092 * * * \\
(0.001)\end{array}$ & $\begin{array}{l}-0.0088^{* * *} \\
(0.001)\end{array}$ & $\begin{array}{l}-0.0078 * * * \\
(0.001)\end{array}$ \\
\hline Precipitation $(\mathrm{t}-1)$ & $\begin{array}{l}-0.0081 * * * \\
(0.001)\end{array}$ & $\begin{array}{l}-0.0064 * * * \\
(0.001)\end{array}$ & $\begin{array}{l}-0.0085^{* * *} \\
(0.001)\end{array}$ & $\begin{array}{l}-0.0067 * * * \\
(0.001)\end{array}$ & $\begin{array}{l}-0.0072 * * * \\
(0.001)\end{array}$ \\
\hline Precipitation $(\mathrm{t}-2)$ & $\begin{array}{l}-0.0035^{* * *} \\
(0.000)\end{array}$ & $\begin{array}{l}-0.0034 * * * \\
(0.001)\end{array}$ & $\begin{array}{l}-0.0039 * * * \\
(0.001)\end{array}$ & $\begin{array}{l}-0.0024 * * * \\
(0.001)\end{array}$ & $\begin{array}{l}-0.0009 \\
(0.001)\end{array}$ \\
\hline Temperature (t) & $\begin{array}{l}0.0631 * * * \\
(0.003)\end{array}$ & $\begin{array}{l}0.0088 * * \\
(0.004)\end{array}$ & $\begin{array}{l}0.0553 * * * \\
(0.005)\end{array}$ & $\begin{array}{l}0.0535^{* * * *} \\
(0.011)\end{array}$ & $\begin{array}{l}0.1425 * * * \\
(0.010)\end{array}$ \\
\hline Temperature $(\mathrm{t}-1)$ & & & & & $\begin{array}{l}0.0296 * * * \\
(0.010)\end{array}$ \\
\hline Observations & 2679 & 846 & 564 & 564 & 705 \\
\hline Regional effects & Yes & Yes & Yes & Yes & Yes \\
\hline Year effects & Yes & Yes & Yes & Yes & No \\
\hline Fixed effects $\mathrm{R}^{2}$ & 0.240 & 0.304 & 0.322 & 0.313 & 0.072 \\
\hline $\mathrm{R}^{2}$ & 0.587 & 0.516 & 0.658 & 0.648 & 0.766 \\
\hline
\end{tabular}

Robust standard errors are reported in parentheses

$* * *, * *$, and $*$ present the $1 \%, 5 \%$ and $10 \%$ significance level respectively

Table 5 Relationship between weather variables and area burnt without differentiating for seasonal effects

\begin{tabular}{|c|c|c|c|c|c|}
\hline Variables & All regions & North & Central North & Central South & South \\
\hline Precipitation (t) & $\begin{array}{l}-0.0127 * * * \\
(0.001)\end{array}$ & $\begin{array}{l}-0.0086^{* * *} \\
(0.001)\end{array}$ & $\begin{array}{l}-0.0105^{* * *} \\
(0.002)\end{array}$ & $\begin{array}{l}-0.0118^{* * *} \\
(0.002)\end{array}$ & $\begin{array}{l}-0.0105^{* * *} \\
(0.002)\end{array}$ \\
\hline Precipitation $(\mathrm{t}-1)$ & $\begin{array}{l}-0.0114 * * * \\
(0.001)\end{array}$ & $\begin{array}{l}-0.0079 * * * \\
(0.001)\end{array}$ & $\begin{array}{l}-0.0116^{* * *} \\
(0.002)\end{array}$ & $\begin{array}{l}-0.0089 * * * \\
(0.001)\end{array}$ & $\begin{array}{l}-0.0096 * * * \\
(0.002)\end{array}$ \\
\hline Precipitation $(\mathrm{t}-2)$ & $\begin{array}{l}-0.0053 * * * \\
(0.001)\end{array}$ & $\begin{array}{l}-0.0040 * * * \\
(0.001)\end{array}$ & $\begin{array}{l}-0.0045^{* *} \\
(0.002)\end{array}$ & $\begin{array}{l}-0.0039 * * * \\
(0.001)\end{array}$ & $\begin{array}{l}-0.0002 \\
(0.002)\end{array}$ \\
\hline Temperature (t) & $\begin{array}{l}0.0907 * * * \\
(0.008)\end{array}$ & $\begin{array}{l}0.0493 * * * \\
(0.012)\end{array}$ & $\begin{array}{l}0.0630 \text { *** } \\
(0.013)\end{array}$ & $\begin{array}{l}0.0785^{* * *} \\
(0.018)\end{array}$ & $\begin{array}{l}0.2162 * * * \\
(0.017)\end{array}$ \\
\hline Temperature $(\mathrm{t}-1)$ & & & & & $\begin{array}{l}0.0585^{* * * *} \\
(0.016)\end{array}$ \\
\hline Observations & 2679 & 846 & 564 & 564 & 705 \\
\hline Regional effects & Yes & Yes & Yes & Yes & Yes \\
\hline Year effects & Yes & Yes & Yes & Yes & No \\
\hline Fixed effects $\mathrm{R}^{2}$ & 0.261 & 0.348 & 0.247 & 0.247 & 0.071 \\
\hline $\mathrm{R}^{2}$ & 0.537 & 0.516 & 0.510 & 0.577 & 0.745 \\
\hline
\end{tabular}

Robust standard errors are reported in parentheses

$* * *, * *$, and $*$ present the $1 \%, 5 \%$ and $10 \%$ significance level respectively

time (i.e., the effects of previous months' weather conditions on fire events and area burnt become increasingly lower in time). Finally, looking at the additional explanatory power of weather conditions, a good portion of the monthly variations in fire events (area burnt) is 
explained by variations in weather variables (i.e., between $20 \%$ and $70 \%$ of the monthly variation in fire events and area burnt is explained by the weather factors). ${ }^{14}$

The results presented in Tables 4 and 5 suggest that the effects of weather variables on fire regime differ across geographical clusters, and from those obtained for the whole Italian peninsula. This outcome, corroborated by a poolability test, suggests the use of different geographical clusters rather than analyzing the whole peninsula together. ${ }^{15}$ In addition, whilst we treated the weather effects as similar across different months and seasons, it is reasonable to expect that their effects differ across months. For instance, in Table 4, we found that the precipitation levels have lasting effects in time on forest fire events for all geographical clusters, however these lasting effects of precipitation are likely to be different across different months. Therefore, in the next subsections, we examine the relationships between weather factors and forest fire variables in a given month for different geographical clusters of Italy.

\subsection{Disentangling the Effects of Monthly Weather on Fire Frequency}

In this subsection, we disentangle the effects of weather variables on forest fire events across the months for different geographical clusters of Italy where the findings are offered in four different panels in Table 6. Panels A and B of Table 6 provide results for the north and central-north of Italy identifying the complexity of the fire cycles in these regions across different months. For almost all months, higher monthly precipitation levels decrease the number of fire events in the same month. Lasting effects of precipitation levels exist but do not show a definite path and furthermore the effect of precipitation declines in time (i.e., the effect of precipitation in previous months is lower). Temperature presents a different effect on the number of fire events. While in the northern Italy (except for February, May, and September), a rise in temperature levels leads to increases in fire events in respective months (see Panel A of Table 6). Whereas, in the central-north, changes in temperature explain the fire events between June and November. After considering the region effects, the additional explanatory power of weather variables is predominant during December and January (i.e., winter season), and in June and July (i.e., summer period) in the northern Italy. Whereas, the greater portion of the fire events between February and April, and between July and November are explained with the variation in precipitation and temperature levels in the central-north of Italy.

In terms of their relationships with fire events, a similar situation can be observed when we move to the central-south, compared to north and central-north of Italy, for both precipitation and temperature, although different paths emerge across the months (see Panel C of Table 6). Lasting effects of more humid climate occur as increases in precipitation levels in a given month, between May and October, not only decrease the number of fire events in the same month but also in the following ones. Similarly, increases in temperature between April and September lead to higher number of fire events. Yet, the variation in temperature levels during the winter period (October-December and January-March) has no significant effect on fire

\footnotetext{
14 The additional explanatory power of weather factors is obtained by the differences between the $R$-square values obtained when regional and time dummies, and weather variables are included in the analysis (i.e., when all relevant factors are included in the analysis) and the R-square values obtained when only the regional and time dummies are used in analysis.

15 We conducted likelihood-ratio (LR) tests to examine whether the different geographical clusters can be pooled together. We reject the null hypothesis that assumes homogenous slope coefficients across different geographical clusters, which suggests that different geographical clusters cannot be pooled together to examine the relationship between weather factors and fire events (area burnt).
} 


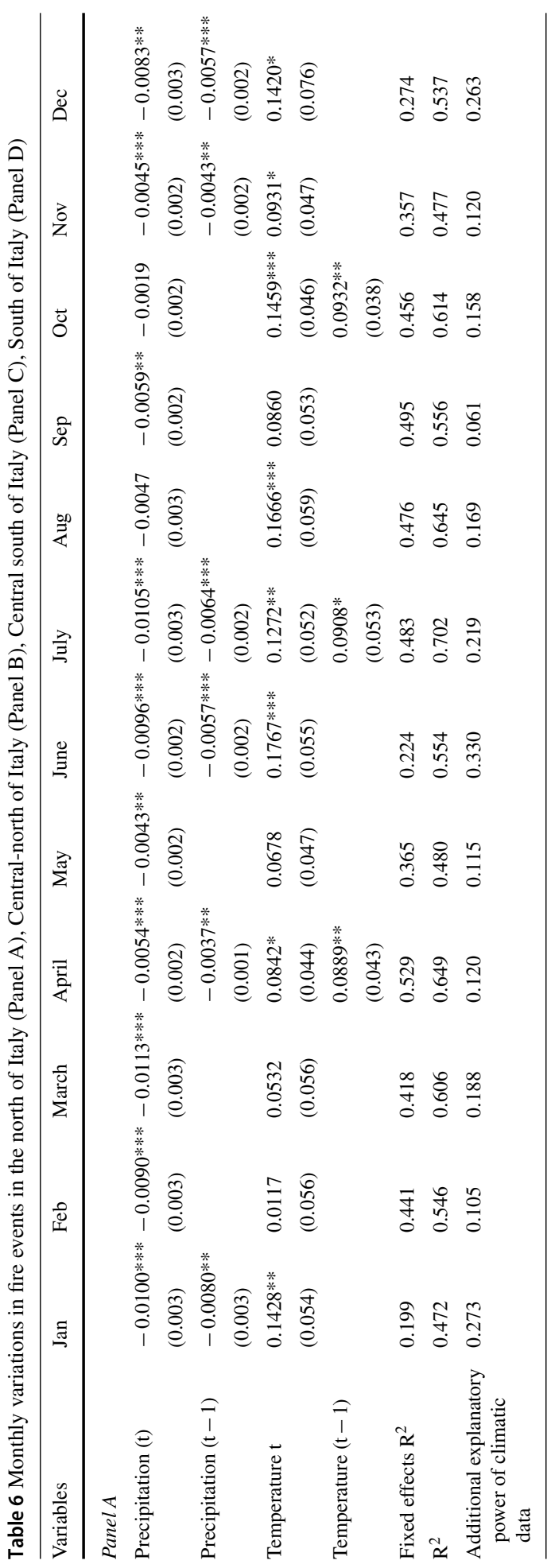




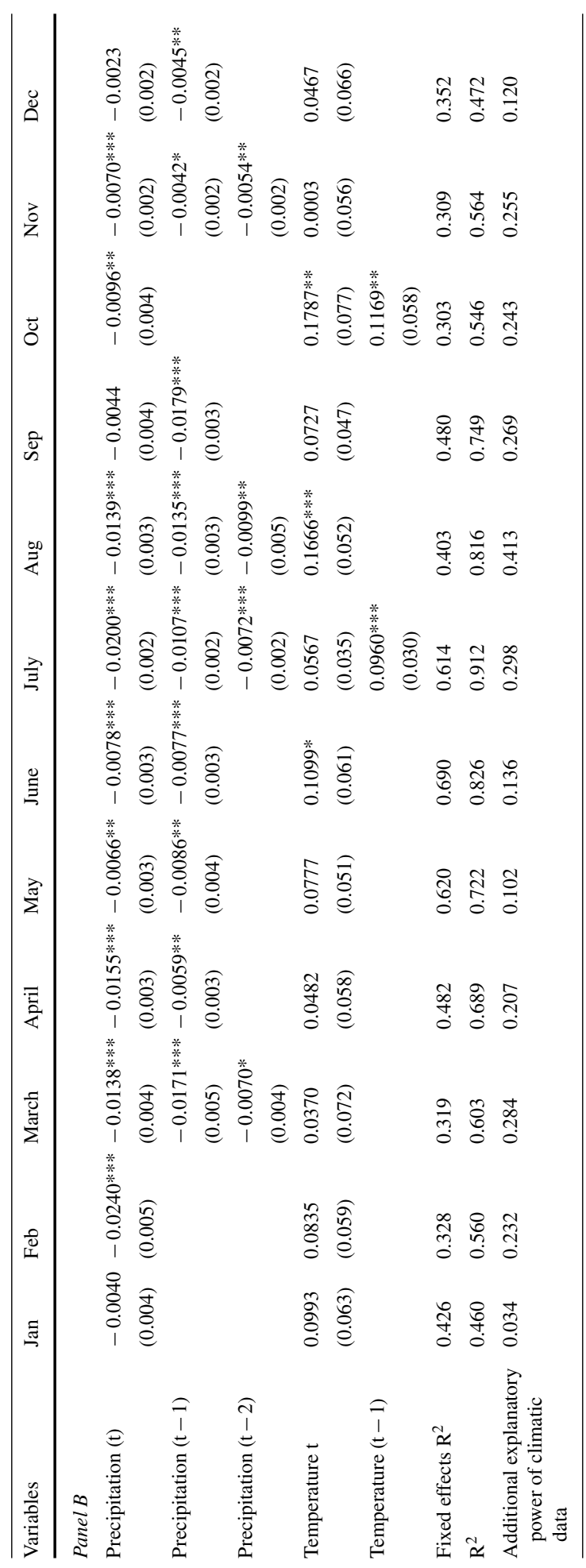




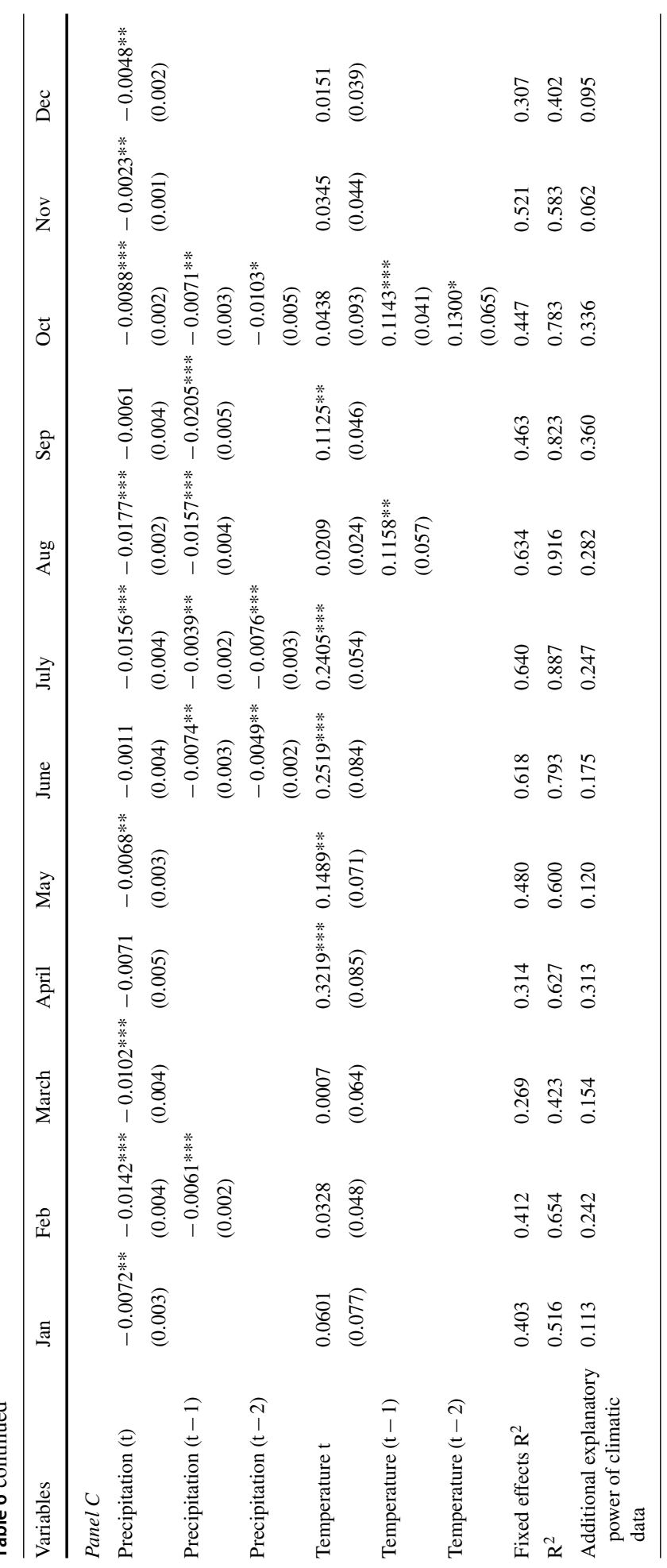




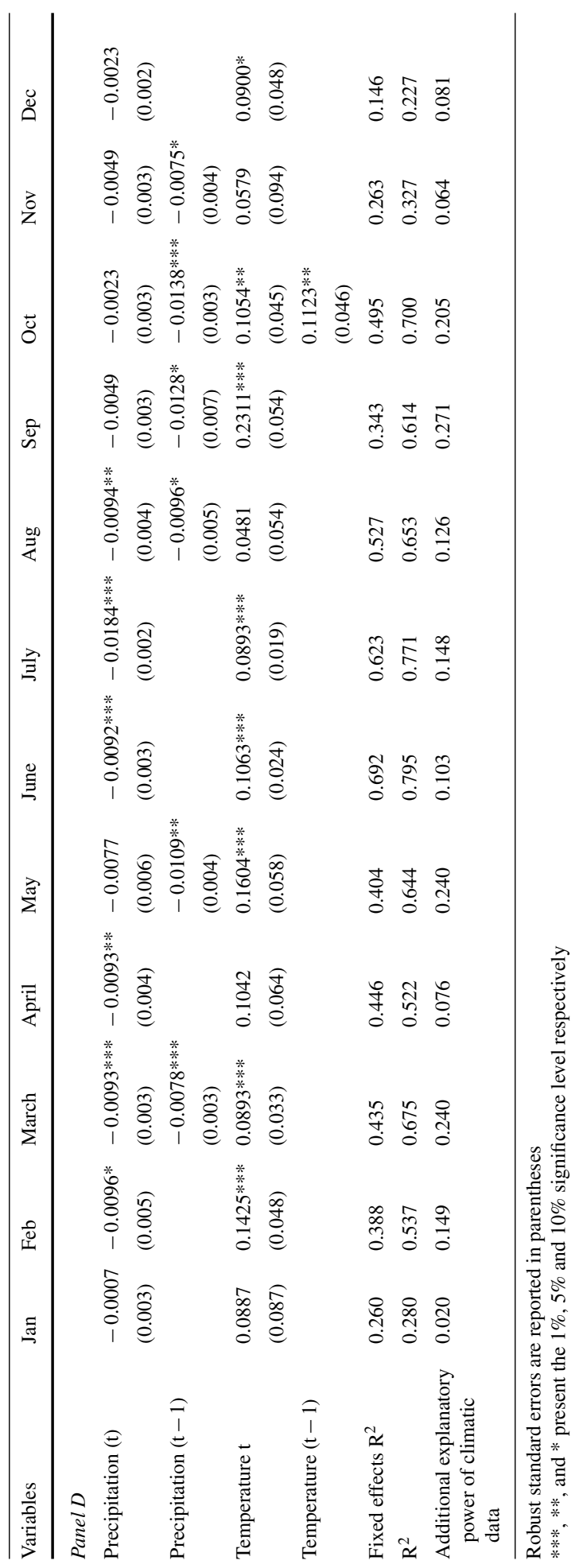


events. We can also observe that except for few months, the additional explanatory power of weather variables is high, after accounting for region-specific fixed effects.

Compared to other regions, despite precipitation still explains the monthly variations in fire events, the effect in the south is relatively lower (see Panel D of Table 6). Variation in precipitation levels during the winter period (November, December, and January) has no direct or lasting effect. However, precipitation levels during the spring, summer and autumn still show significant effects. One aspect that differs from other geographical areas is that temperature levels in February and March explain the variation in fire events in these months at the $1 \%$ significance level. However, fire frequency in August seems to be affected by the precipitation levels in the same period and in the previous month, rather than by temperature, signalling a greater impact played by drought rather than by a warm climate.

\subsection{Disentangling the Effects of Monthly Weather on the Area Burnt}

In this subsection, we conduct a similar empirical analysis to Sect. 4.2, however, we now we examine the weather factors' relationships with the total area burnt across different geographical clusters where the findings are reported in four panels of Table 7.

More specifically, Panel A of Table 7 reports our findings for the northern Italy. We find that the regional fixed effects explain between $20 \%$ and $60 \%$ of the variation in the area burnt during the specific months in the case of northern Italy (i.e., see R-square values obtained with the fixed effects in Panel A of Table 7). After controlling for region specific effects, weather variables still explain a good portion of the variation in area burnt during a given month, except for few cases. Higher precipitation levels lead to lower land burnt in almost all months except for April, August, and October. During winter (October-December) precipitation increases have persistent declining effects on the area burnt, highlighting the importance of humid climate in mitigating the spread of fire events across larger areas. Relatively warmer temperatures lead to increases in area burnt for almost the entire year. The persistency of the effects of temperature is limited compared to effects of precipitation on area burnt.

In the central-north of Italy, instead, temperature levels appear to be significant only for June and August, while the effect of warmer temperatures in June and September lasts until July and October (see Panel B of Table 7). On the other hand, precipitation levels are significant and negatively associated with the area burnt in a given month (with the only exception of January), emphasizing the relevance of soil moisture which minimizes the total area burnt during the fire events. Lasting effects of precipitation take place during the spring (February-April) and summer (June-August) periods. Higher precipitation in these periods reduces the portion of area burnt in consecutive months underlining the relevance of humid climate in mitigating the spread of fire events across larger areas. Weather variables in summer explain additional $20 \%, 43 \%$, and $62 \%$ of the area burnt variation from June, July, and August, respectively. This is an important result since $67 \%$ of the total area was burnt in this geographical cluster between 2000 and 2011 precisely during this season.

Panel C of Table 7 offers the detailed findings for the central-south of Italy. For most of the winter period (November to February), the monthly precipitation explains the variation in area burnt in respective months. High temperature and low precipitation levels in consecutive months between July and October lead to higher area burnt in the same months. Weather variables explain additional 39\%, 42\%, 42\%, and 34\% of the variation in July, August, September, and October, respectively. Like the central-north, $89 \%$ of the total area burnt between 2000 and 2011 occur in these months highlighting the importance of the weather factors. Finally, the lasting negative effects of precipitation on reducing the burnt area is an 


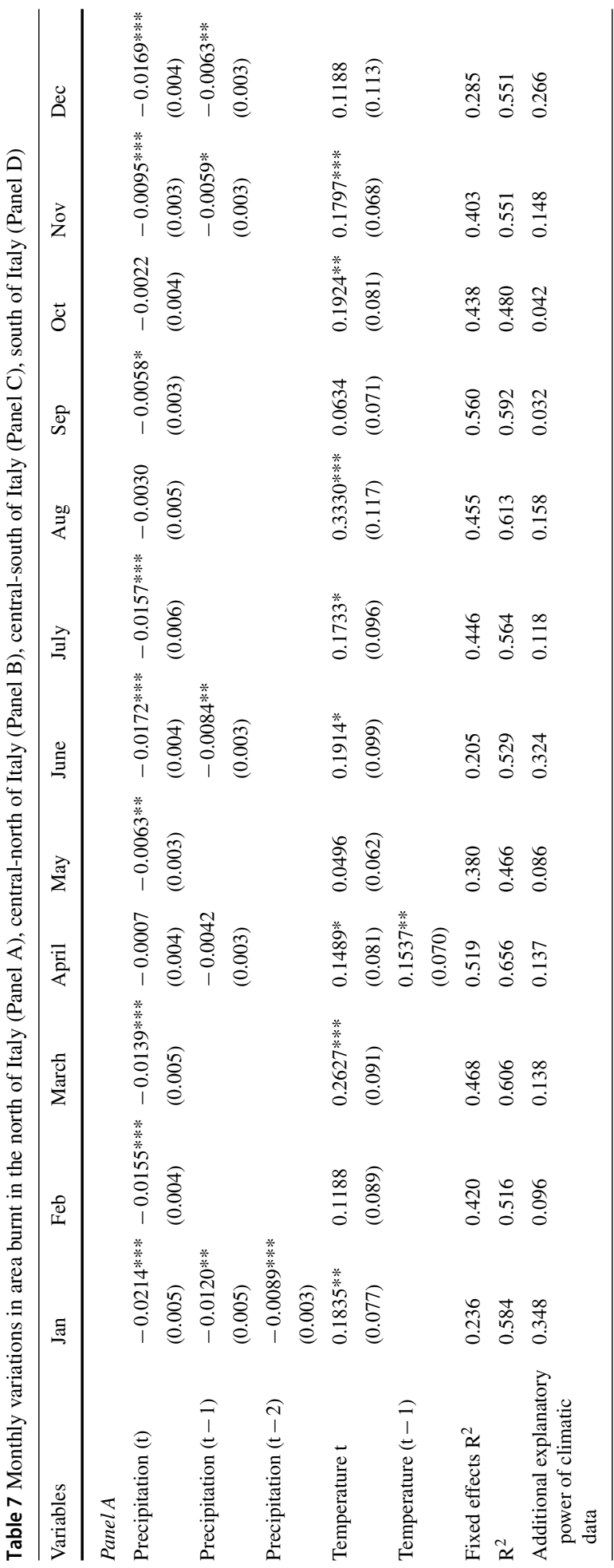




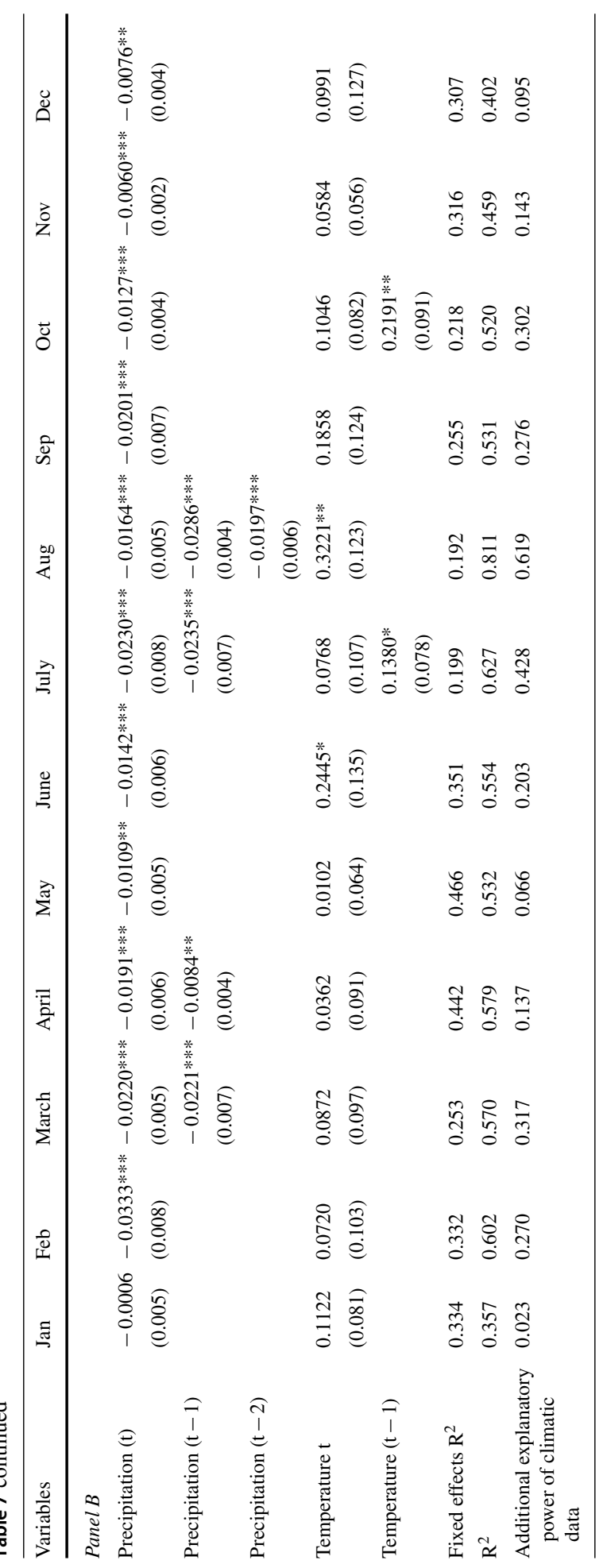




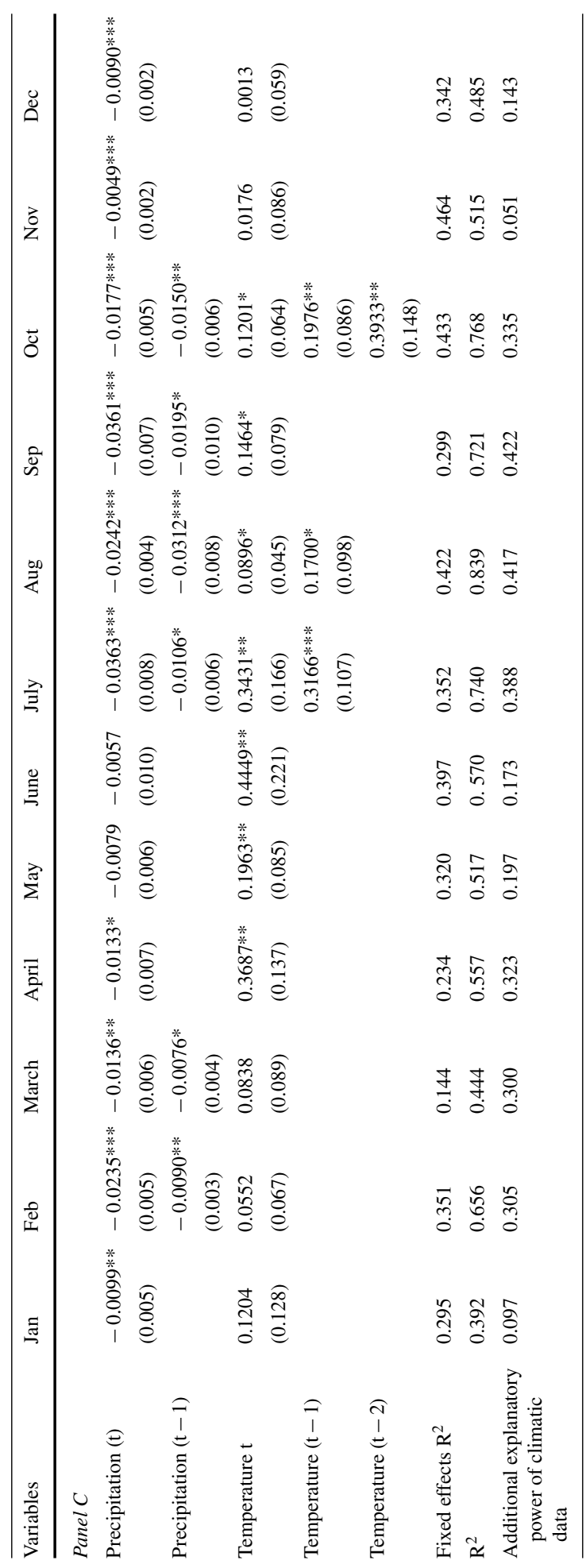




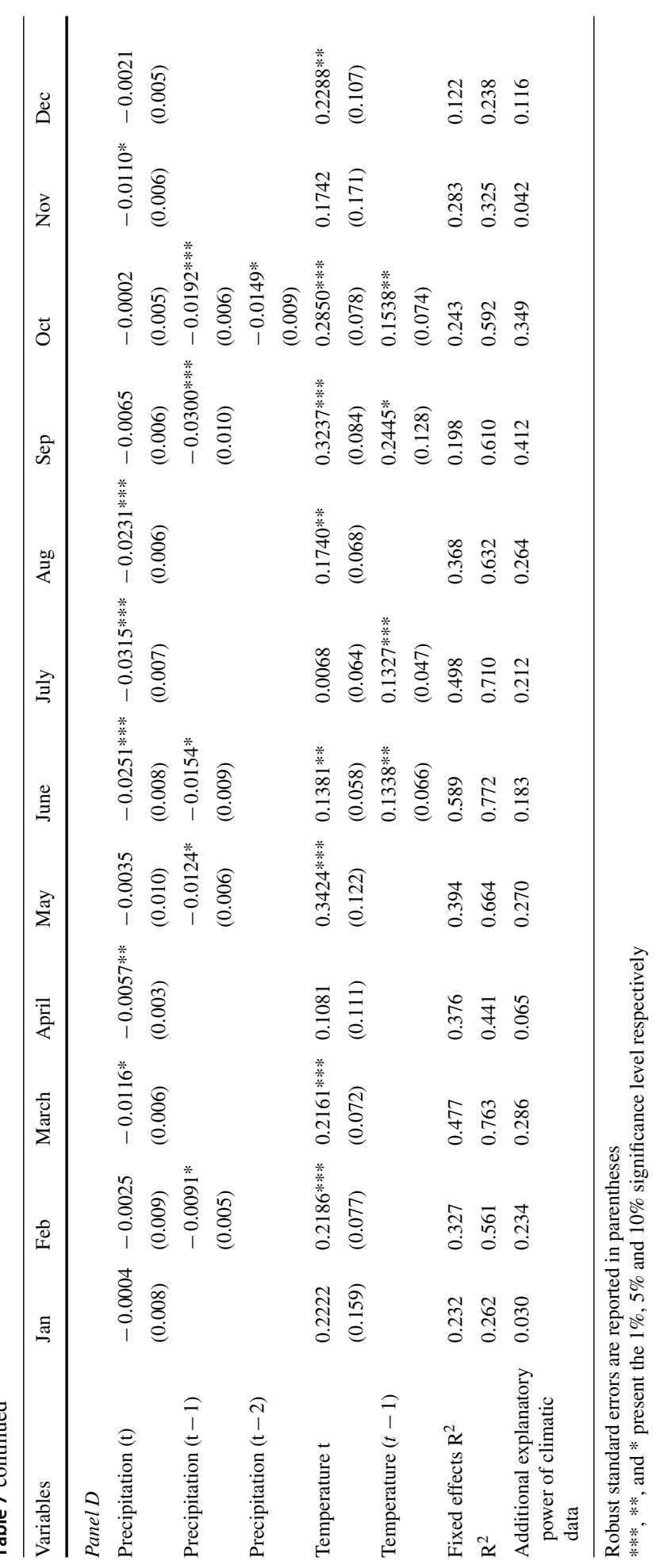


important factor for the spring period where the weather variables' additional explanatory power during the spring period (February-April) is $30 \%$.

Variation in temperature levels across the months is relatively more important in the south of Italy than in any other geographical cluster where high temperature in a given month and/or previous month leads to more area burnt in all months with the exceptions of January, April, and November (see Panel D of Table 7 for detailed findings for the south of Italy). Similarly, lower levels of precipitation extend the portion of land burnt in all months except for January and December. Therefore, we can suggest that drought (i.e., low precipitation and high temperature levels) plays an important role in explaining the variation in area burnt between May-July and September-October. This finding is particularly important since 96\% of the area gets on fire between May and October in south Italy. Overall, we can summarize that the relatively high temperature and low precipitation, or a combination of the two (i.e., drought), explain between $18 \%$ and $41 \%$ of the variation in area burnt in all months but the winter period (November, December, and January) in the south of Italy after controlling for the region-specific factors.

\subsection{Climate Change Implications}

In this subsection, we use the first and second climate scenarios (see Tables 1 and 2) to present predicted number of fire events and area burnt during the winter (DJF), spring (MAM), summer (JJA), autumn (SON), and annually for different geographical clusters of Italy by using the significant coefficients on weather variables from Tables 6 and 7, respectively. Projected forest fire events and area burnt for each geographical cluster are for 2016-2035 period relative to 2000-2005 period to be consistent with the climate scenarios. It should be noted that climate scenarios 1 and 2 can be considered as conservative as they average the projected levels of temperature and precipitation variation simulated by climate models (see Sect. 2.1). Table 8 reports the projected percentage changes in fire events and area burnt in different seasons for four geographical clusters of Italy with both climate change scenarios (see Appendix Tables 11 and 12 for the detailed fire event and area burnt projections for geographical clusters with climate scenarios 1 and 2, respectively).

Climate changes exert a pressure on fire regime in both climate scenarios from north to south suggesting an increase fire frequency and land burnt during the period between 2016 and 2035. The annual number of fire events in the north, central-north, central-south and south of Italy is projected to increase by $\sim 11-12 \%, 16 \%, 25 \%$, and $9-10.5 \%$, respectively. Clearly, the effects of climate change on fire events varies across geographical clusters where the effect of climate change would affect the central Italy the most compared to other regions. On the other hand, the seasons in which forest fire event increments are different across different geographical clusters. Major increases in forest fires in the north of Italy is projected to be in the winter and summer periods. In the central-north, most of the annual increase is driven by fires occurring in the summer period. For the central-south of Italy, fire events are projected to increase by $30 \%$ and $20 \%$, during summer and autumn, accounting for additional 300 and 50 fire occurrences, respectively. Finally, the highest annual percentage increase in fire events in southern Italy is expected to be during the autumn period (ranging between 19\% and 27\% depending on the scenario). Overall, even though there is a major increase in summer fire events for all clusters, projections also highlight a rise of autumn fire events compared to the past, especially in the central-south and south of Italy.

A clear distinction between results obtained about fire frequency and those relative to the variation of land burnt, as a function of climate change, is that the portion of land affected by 
Table 8 Projected percentage changes in fire events and area burnt with the climate change

\begin{tabular}{|c|c|c|c|c|c|}
\hline \multirow{2}{*}{$\begin{array}{l}\text { Geographical } \\
\text { clusters }\end{array}$} & \multirow[t]{2}{*}{ Time frame } & \multicolumn{2}{|l|}{ Scenario 1} & \multicolumn{2}{|l|}{ Scenario 2} \\
\hline & & Fire events & Area burnt & Fire events & Area burnt \\
\hline \multirow[t]{5}{*}{ Northern Italy } & Winter (DJF) & 13.81 & 19.33 & 12.78 & 14.91 \\
\hline & Spring (MOM) & 9.32 & 38.14 & 4.89 & 32.34 \\
\hline & Summer (JJA) & 16.90 & 35.73 & 17.55 & 36.01 \\
\hline & Autumn (SON) & 3.65 & 5.17 & 5.95 & 7.21 \\
\hline & Annual & 12.01 & 26.60 & 10.58 & 23.08 \\
\hline \multirow{5}{*}{$\begin{array}{l}\text { Central-north } \\
\text { Italy }\end{array}$} & Winter (DJF) & 2.01 & 2.83 & 2.01 & 2.83 \\
\hline & Spring (MOM) & 4.17 & 4.99 & 4.17 & 4.99 \\
\hline & Summer (JJA) & 24.27 & 52.41 & 24.27 & 52.41 \\
\hline & Autumn (SON) & 5.21 & 5.38 & 4.84 & 5.29 \\
\hline & Annual & 15.93 & 34.54 & 15.89 & 34.53 \\
\hline \multirow{5}{*}{$\begin{array}{l}\text { Central-south } \\
\text { Italy }\end{array}$} & Winter (DJF) & 3.01 & 4.82 & 3.01 & 4.82 \\
\hline & Spring (MOM) & 13.95 & 15.13 & 15.16 & 16.46 \\
\hline & Summer (JJA) & 29.95 & 86.02 & 29.95 & 86.02 \\
\hline & Autumn (SON) & 20.86 & 44.30 & 18.98 & 40.66 \\
\hline & Annual & 25.37 & 75.02 & 25.23 & 74.62 \\
\hline \multirow[t]{5}{*}{ Southern Italy } & Winter (DJF) & 7.25 & 12.46 & 7.25 & 12.46 \\
\hline & Spring (MOM) & 13.76 & 20.50 & 11.75 & 19.05 \\
\hline & Summer (JJA) & 6.58 & 21.02 & 6.58 & 21.25 \\
\hline & Autumn (SON) & 26.74 & 70.79 & 19.47 & 71.48 \\
\hline & Annual & 10.52 & 25.55 & 9.13 & 25.77 \\
\hline
\end{tabular}

fires is projected to expand in all geographical clusters. Climate change could favor fire danger and propagation and lead to the occurrence of more extreme fire events (i.e., fire events that result in larger areas being burnt), procuring higher damage to humans and ecosystems and requiring more costly suppression activities. ${ }^{16}$ This could be the result of the effect of climate change on moisture dynamics and alteration of fire susceptibility in specific regions; effects that are captured by the panel data estimation methods employed. From north to south, across all geographical clusters, land areas burnt are projected to increase by $23-27 \%, 34 \%, 75 \%$, and $26 \%$ per annum (see Table 8 for area burnt projections). As a result, around additional $2400,1100,9000$, and 11,000 ha of forest area will be touched by fire in north, centralnorth, central-south, and south of Italy, respectively (see Appendix Tables 11 and 12 for the details). These annual values are mostly driven by fire dynamics taking place during summer. However, percentage increases in the area burnt under climate change are relatively higher during autumn in central-south and south of Italy, suggesting higher suppression challenges and damage effects on land for these two clusters in the future. Finally, even though in north Italy the increase in the number of fire events in spring is limited, the area burnt during the same period is expected to raise by $1200-1300$ ha in the two scenarios.

16 In this paper, we analyze the total area burnt during a given month not the extreme events themselves, but the findings of this paper suggest that on average, each fire event would result in more area burnt with the climate change anomalies. 


\subsection{Yearly Variations in the Fire Events and Area Burnt and the Role of Socio-economic Factors}

To test the relevance of socio-economic variables in explaining the fire events and area burnt, we move to a yearly-based analysis since the data on socio-economic factors are only available on yearly basis. The relevance of weather variables' effect on fire events and area burnt has been highlighted using monthly panel data estimations where they have been found to play a varying role in different seasons across different geographical clusters. In the following regressions, annual averages of precipitation and temperature have been included as control variables.

Panels A and B of Table 9 report the statistically significant socio-economic factors when the dependent variable is the natural logarithm of fire events and area burnt, respectively, even though the list of explanatory variables that were used in this analysis is provided in Appendix Table $10 .^{17}$

Our findings suggest a negative relationship between education levels and fire regime in most of the Italian areas, after the inclusion of regional dummies and weather variables in regression analyses. A percentage increase in tertiary education in north, central-north and central-south of Italy leads to a decrease of $11 \%, 7 \%$, and $2.2 \%$ in fire events, respectively. It should be noted that the fixed effect model (i.e., the estimation model that includes regional dummies) is designed to examine the causes of changes within a region over-time. The effect of education can be captured only when regional dummies are included. ${ }^{18}$ Despite the fact that it is rarely investigated within the literature, the resulting relation between education level and fire "hazard" appears to be supportive of existing studies. Locations characterized by low instruction level show higher fire risk (de Torres Curth et al. 2012). In principle, education level can affect forest regime both directly and indirectly. For example, education plays an important role in determining the distribution of income: higher level of educational attainment improves income levels and reduces income inequality (Glaeser et al. 2004; Crespo Cuaresma et al. 2013; Coady and Dizioli 2018, among many others) which may then increase the resources available for firefighting and prevention.

Beyond the importance of education levels we also find that in southern regions, illegal activities represent an additional driver after accounting for the regional effects and weather factors. A marginal (unit) increase in extortion activities per 100,000 inhabitant leads to increases in fire frequency and total area burnt by $4.6 \%$ and $7 \%$, respectively. This finding is in accordance with the literature suggesting the importance of human induced and intentional forest fires (Leone et al. 2002; Bovio et al. 2017).

In sum, even though major drivers of seasonal fires are due to weather factors, annual variations in fire events and area burnt are also closely linked with some of the socio-economic factors and improvements in education levels and fighting against illegal activities on humaninduced fires could mitigate the ever-increasing pressure of climate change's impact on forest fires.

\footnotetext{
17 All the variables listed in the Appendix Table 10 are used in the regressions one at a time after controlling for the yearly variation in temperature and precipitation. However, most of the variables were not significant once weather variables are accounted for. Additionally some of the variables produce high multicollinearity (i.e., high VIF values) and hence they are dropped from the regressions (see e.g., Vadrevu et al. 2006; Martinez et al. 2009 for similar procedure).

18 For instance, when we do not include regional dummies in our regressions and utilize pooled ordinary least squares (OLS) estimations, we do not find any significant relationship between education and forest fires.
} 


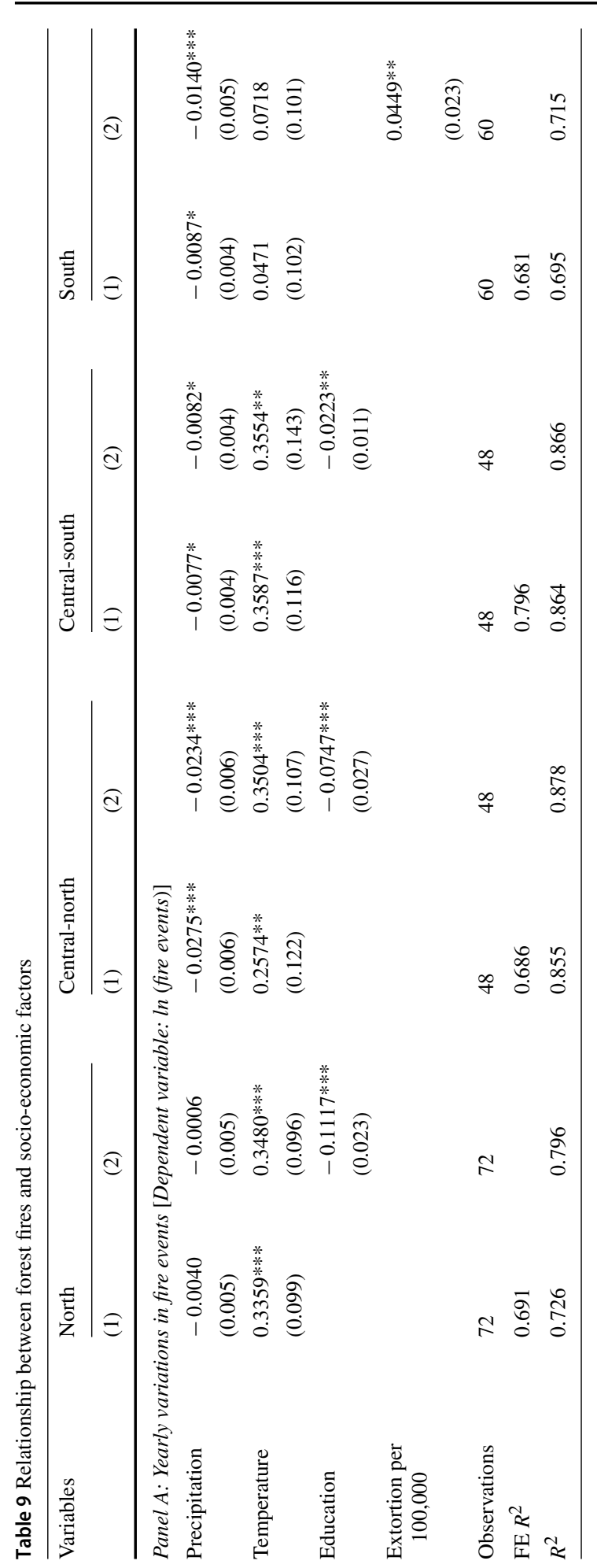




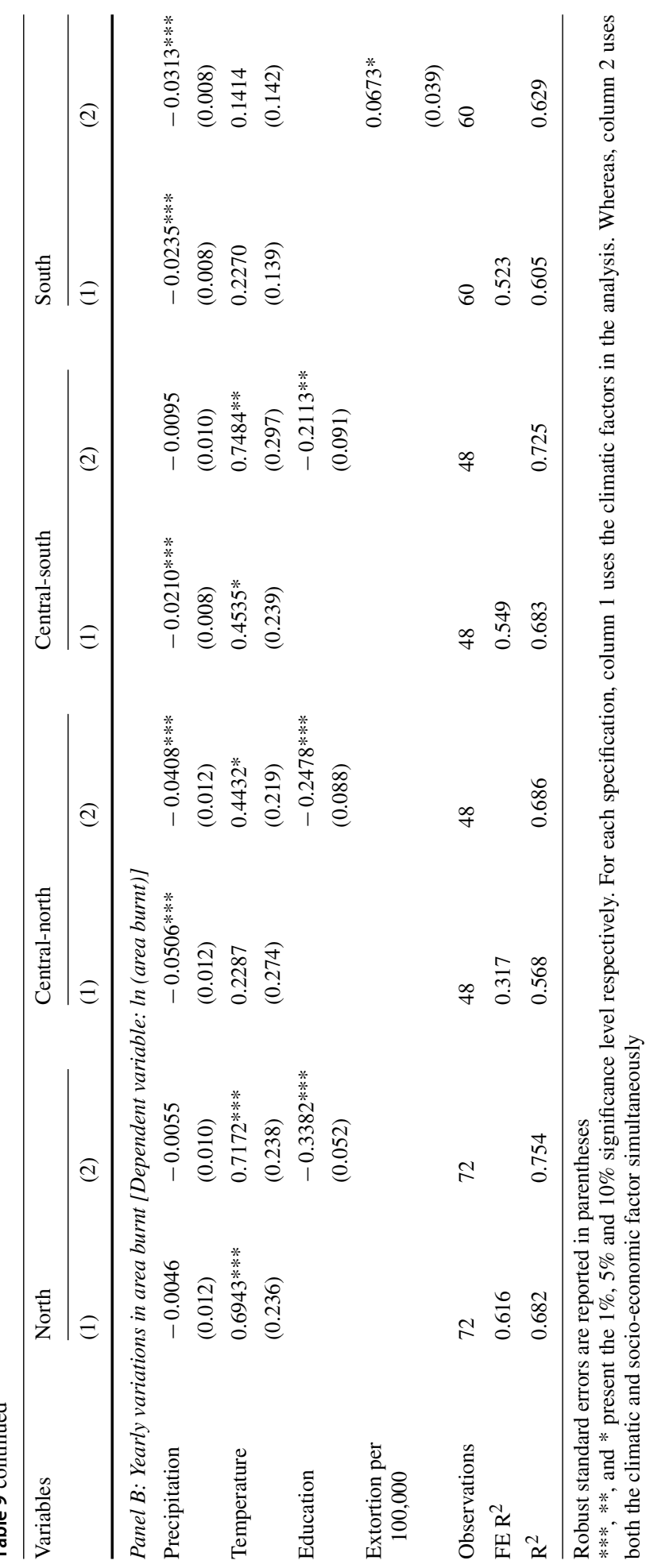

算 Springer 


\section{Concluding Remarks}

We analyze the contributions of weather (i.e., temperature and precipitation) and socioeconomic factors in explaining fire regime (i.e., number of event and area burnt) across four geographical clusters in Italy (north, central-north, central-south, and south) between 2000 and 2011. Panel data estimation techniques allowed us to obtain the effects of weather factors on forest fires after controlling for region-specific time-invariant factors and fire temporal dynamics.

Results highlight a clear regional heterogeneity across space and time where the regional fixed effects explain a good portion of the variation in forest fire events and area burnt. Each region has their own morphological, meteorological, socio-economical, and cultural characteristics. From area to area, high temperatures, water stress caused by low rainfall are responsible of the total fire scenario. Time and region effects included in the model through the panel estimation technique have proven to be relevant. While these effects are not identified in most studies, our results suggest that they should be controlled for by the future studies.

Furthermore, our study highlighted the fact that the effects of weather factors on fire regime show variation across seasons and geographical locations. In the north of Italy, weather conditions can explain fire regime in different months identifying its plurimodal distribution. In addition, variation in temperature and precipitation can show lasting effects in time. The same is true for central-north where effects of precipitation taking place around spring and summer periods also last in the following months. For central-south we observe a bi-modal distribution of fire data as the greatest explanatory power of weather factors is associated to the periods of February-April and July-October. For the south, three major fire periods can be disentangled during a year: February-March, May, and July-October. Consecutive high temperature and low precipitation levels during autumn (i.e., high drought levels in autumn) increase fire events and area burnt in the same period in the southern Italy.

By projecting fire regime as a function of future climate change, we observe that all clusters show an annual increase in the number of events and area burnt between 2016 and 2035 relative to the period of 2000-2005. The most affected area will be the central-south of Italy, with fire events and area burnt are projected to increase by $25 \%$ and $75 \%$, respectively. Northern Italy will experience a higher fire frequency during the winter period, while in the central-north the annual rise in frequency is mostly driven by the projected fire events during the summer season. Central-south is projected to experience $30 \%$ and $20 \%$ increase in the number of fires during the summer and autumn periods, respectively. Overall, while most frequent fire events will occur mainly in summer, confirming the past trends, a new path is reported for fires taking place in the central-south and south of Italy during the autumn period, which highlights the importance of more fire suppression efforts during autumn period in the central-south and south of Italy than the ones observed in the past. Finally, it is worth noting that the projected increases in area burnt in the northern Italy is expected to increase even though the projected increase in fire events is at modest levels. This increase in spread of fire could be a result of the impact of climate change on soil conditions, moisture content of litter and other fine fuels. The fire season could then become longer, more intense and extreme as reduced rainfall, heat waves, and drought events increase the water stress of the vegetation making it highly flammable. In sum, compared to the past, our findings suggest that there is clear change in the forest fire phenomenon across different seasons and geographical clusters and the interactions of climatic factors and forests have new connotations. 
Beyond weather parameters, socio-economic factors also contributes to the explanation of forest fire regimes. Higher levels of education lead to decreases in the number of fire events and total area burnt in all geographical clusters with the exception of southern Italy. Whereas, a major contribution to fire regime in the southern Italy is due to the existence of criminal activity, exerting pressure on forest land. These two socio-economic factors are found to be important in explaining yearly variation in forest fires and area burnt after controlling for regional effects and weather variables.

The projected situation in fire regime calls for the development of initiatives to reduce risks of forest fires and their potential environmental and socio-economic impact.

On the one hand, a containment of the effects can be achieved through increasing education and awareness to foster protection of common goods. On the other hand, the solution may come from a revision of the present forest and fire management strategies, currently relying almost exclusively on extinction and emergency response, rather than monitoring and prevention, resulting in high costs and partial efficacy in extreme fire seasons. Rather than working at suppressing fires, it would be more efficient and effective to invest in fire prevention, implementing active forest management and active surveillance. Land and fuel management could also help in fuel-oriented silviculture, facilitating less flammable species or using prescribed burning to mitigate fire intensity. Prevention at lower costs can involve the revitalization of the economy through recreational and cultural tourism, biomass use, timber production, and protection of forest food products. Contrasting forest abandonment and deterioration allows for a larger supply of forest products and reduces the vulnerability to fires.

The implementation of these strategies would require a process of governance reorganization for the whole sector. However, despite the forest land represents one of the major infrastructure for Italy, this sector has been neglected by politicians. This is also supported by the recent events that have characterized the Italian forest sector lately: the suppression of the Italian police force (Corpo Forestale dello Stato) in charge of the recording of all fire events in the Italian peninsula, and the termination of the recording activity on forest sector statistics by the National Italian Institute for Statistics. These two recent governance decisions will make the monitoring and management of the fire phenomenon more difficult under more extreme climate conditions in the future.

Acknowledgements This work was partially funded by the European Union Seventh Framework Programme (FP7/2007-2013) under Grant Agreement 243888 ("FUME" Project-Forest fires under climate, social and economic changes in Europe, the Mediterranean and other fire-affected areas of the world): http://www.fumep roject.eu/?q=project. Mehmet Pinar also acknowledges the Research Investment Fund of Edge Hill University for their financial support. Additionally, we thank the Italian Corpo Forestale dello Stato and the Joint Research Centre for providing us with data on fires as well as ISTAT for socio-economic data. We would like to thank the participants of the First International Workshop on The Economics of Climate Change and Sustainability for their useful comments to improve the paper. Finally, we thank Renato Rosa, Francesco Bosello, Matteo Manera, and Keith Cook for their comments and precious help.

Open Access This article is distributed under the terms of the Creative Commons Attribution 4.0 International License (http://creativecommons.org/licenses/by/4.0/), which permits unrestricted use, distribution, and reproduction in any medium, provided you give appropriate credit to the original author(s) and the source, provide a link to the Creative Commons license, and indicate if changes were made.

\section{Appendix}

See Tables 10, 11 and 12. 


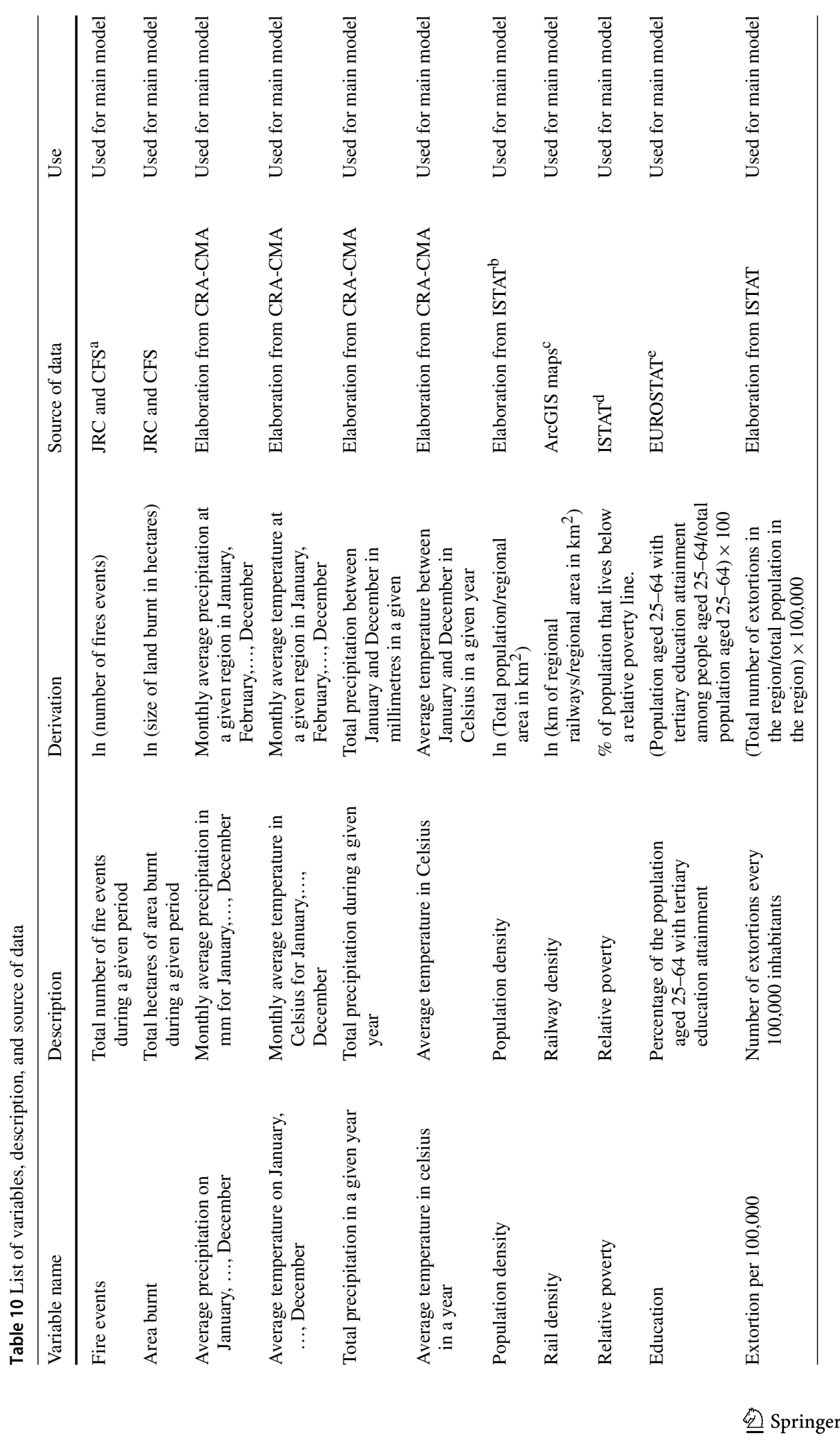




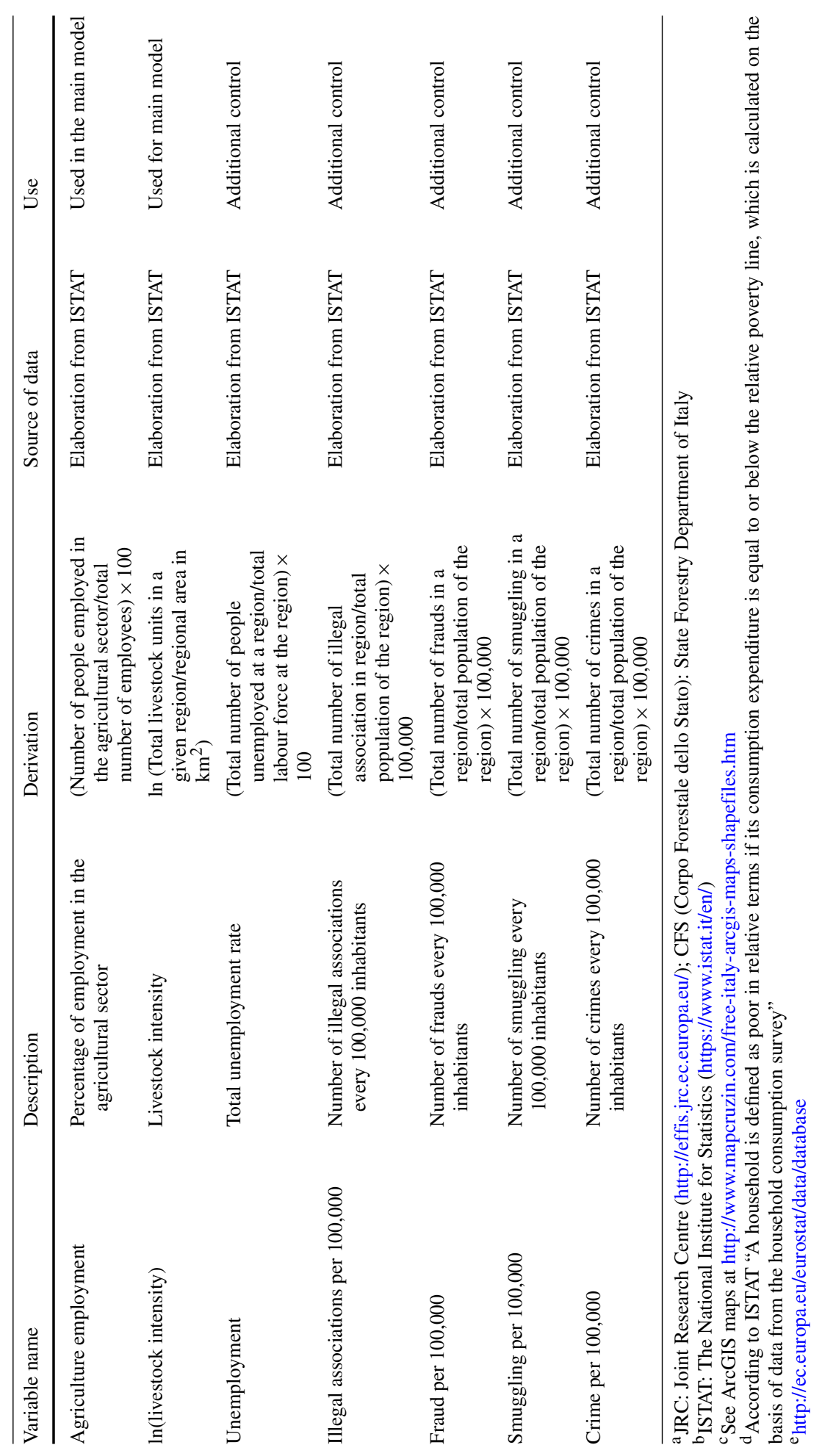


Table 11 Projected effects of climate change on the fire events and area burnt in each geographical cluster with Scenario 1

$\begin{array}{llll}\text { Winter (DJF) } & \text { Spring (MOM) } & \text { Summer (JJA) } & \text { Autumn (SON) }\end{array}$

Panel A: Projected effects of climate change on fire events in each geographical cluster

Projected changes in fire events in northern Italy

\begin{tabular}{|c|c|c|c|c|c|}
\hline $\begin{array}{l}\text { Average events } \\
(2000-2005)\end{array}$ & 418.33 & 447.33 & 322.33 & 134.83 & 1322.83 \\
\hline $\begin{array}{l}\text { Predicted events } \\
(2016-2035)\end{array}$ & 476.12 & 489.03 & 376.81 & 139.75 & 1481.72 \\
\hline $\begin{array}{l}\text { Percentage change in } \\
\text { events }\end{array}$ & 13.81 & 9.32 & 16.90 & 3.65 & 12.01 \\
\hline \multicolumn{6}{|c|}{ Projected changes in fire events in central-north of Italy } \\
\hline $\begin{array}{l}\text { Average events } \\
(2000-2005)\end{array}$ & 66.83 & 144.33 & 426.00 & 86.33 & 723.50 \\
\hline $\begin{array}{l}\text { Predicted events } \\
(2016-2035)\end{array}$ & 68.18 & 150.36 & 529.40 & 90.83 & 838.77 \\
\hline $\begin{array}{l}\text { Percentage change in } \\
\text { events }\end{array}$ & 2.01 & 4.17 & 24.27 & 5.21 & 15.93 \\
\hline \multicolumn{6}{|c|}{ Projected changes in fire events in central-south of Italy } \\
\hline $\begin{array}{l}\text { Average events } \\
(2000-2005)\end{array}$ & 61.17 & 197.00 & 1021.67 & 236.50 & 1516.33 \\
\hline $\begin{array}{l}\text { Predicted events } \\
(2016-2035)\end{array}$ & 63.01 & 224.49 & 1327.69 & 285.84 & 1901.02 \\
\hline $\begin{array}{l}\text { Percentage change in } \\
\text { events }\end{array}$ & 3.01 & 13.95 & 29.95 & 20.86 & 25.37 \\
\hline \multicolumn{6}{|c|}{ Projected changes in fire events in southern Italy } \\
\hline $\begin{array}{l}\text { Average events } \\
(2000-2005)\end{array}$ & 39.33 & 212.17 & 2835.00 & 653.17 & 3739.67 \\
\hline $\begin{array}{l}\text { Predicted events } \\
(2016-2035)\end{array}$ & 42.19 & 241.35 & 3021.58 & 827.81 & 4132.93 \\
\hline $\begin{array}{l}\text { Percentage change in } \\
\text { events }\end{array}$ & 7.25 & 13.76 & 6.58 & 26.74 & 10.52 \\
\hline
\end{tabular}


Table 11 continued

$$
\text { Winter (DJF) } \quad \text { Spring (MOM) } \quad \text { Summer (JJA) } \quad \text { Autumn (SON) } \quad \text { Annual }
$$

Panel B: Projected effects of climate change on area burnt in each geographical cluster

Projected changes in area burnt in northern Italy

\begin{tabular}{|c|c|c|c|c|c|}
\hline $\begin{array}{l}\text { Average area burnt } \\
(2000-2005)\end{array}$ & 4363.01 & 3594.47 & 1550.21 & 1115.15 & $10,622.84$ \\
\hline $\begin{array}{l}\text { Predicted area burnt } \\
(2016-2035)\end{array}$ & 5206.32 & 4965.59 & 2104.04 & 1172.76 & $13,448.71$ \\
\hline $\begin{array}{l}\text { Percentage change in } \\
\text { area burnt }\end{array}$ & 19.33 & 38.14 & 35.73 & 5.17 & 26.60 \\
\hline \multicolumn{6}{|c|}{ Projected changes in area burnt in central-north of Italy } \\
\hline $\begin{array}{l}\text { Average area burnt } \\
(2000-2005)\end{array}$ & 378.20 & 506.55 & 2042.57 & 327.19 & 3254.50 \\
\hline $\begin{array}{l}\text { Predicted area burnt } \\
\quad(2016-2035)\end{array}$ & 388.91 & 531.82 & 3113.07 & 344.78 & 4378.58 \\
\hline $\begin{array}{l}\text { Percentage change in } \\
\text { area burnt }\end{array}$ & 2.83 & 4.99 & 52.41 & 5.38 & 34.54 \\
\hline \multicolumn{6}{|c|}{ Projected changes in area burnt in central-south of Italy } \\
\hline $\begin{array}{l}\text { Average area burnt } \\
(2000-2005)\end{array}$ & 177.56 & 723.94 & 9598.40 & 1619.57 & $12,119.48$ \\
\hline $\begin{array}{l}\text { Predicted area burnt } \\
(2016-2035)\end{array}$ & 186.12 & 833.48 & $17,855.19$ & 2336.98 & $21,211.78$ \\
\hline $\begin{array}{l}\text { Percentage change in } \\
\text { area burnt }\end{array}$ & 4.82 & 15.13 & 86.02 & 44.30 & 75.02 \\
\hline \multicolumn{6}{|c|}{ Projected changes in area burnt in southern Italy } \\
\hline $\begin{array}{l}\text { Average area burnt } \\
(2000-2005)\end{array}$ & 156.66 & 1539.71 & $39,805.69$ & 4209.28 & $45,711.33$ \\
\hline $\begin{array}{l}\text { Predicted area burnt } \\
(2016-2035)\end{array}$ & 176.17 & 1855.29 & $48,171.89$ & 7188.96 & $57,392.32$ \\
\hline $\begin{array}{l}\text { Percentage change in } \\
\text { area burnt }\end{array}$ & 12.46 & 20.50 & 21.02 & 70.79 & 25.55 \\
\hline
\end{tabular}

All projected changes are obtained by using the significant estimates from Tables 6 and 7 for each geographic cluster for the fire events and area burnt, respectively. In this scenario, the projected mean temperature and precipitation levels for May, September and October (November, March and April) are considered to be the same as the respective mean projection for the summer (winter), respectively 
Table 12 Projected effects of climate change on the fire events and area burnt in each geographical cluster with Scenario 2

$\begin{array}{llll}\text { Winter (DJF) } & \text { Spring (MOM) } & \text { Summer (JJA) } & \text { Autumn (SON) }\end{array}$

Panel A: Projected effects of climate change on fire events in each geographical cluster

Projected changes in fire events in northern Italy

\begin{tabular}{|c|c|c|c|c|c|}
\hline $\begin{array}{c}\text { Average events } \\
(2000-2005)\end{array}$ & 418.33 & 447.33 & 322.33 & 134.83 & 1322.83 \\
\hline $\begin{array}{l}\text { Predicted events } \\
\quad(2016-2035)\end{array}$ & 471.80 & 469.23 & 378.90 & 142.86 & 1462.78 \\
\hline Percentage change in & 12.78 & 4.89 & 17.55 & 5.95 & 10.58 \\
\hline
\end{tabular}

$$
\text { events }
$$

Projected changes in fire events in central-north of Italy

\begin{tabular}{|c|c|c|c|c|c|}
\hline $\begin{array}{l}\text { Average events } \\
(2000-2005)\end{array}$ & 66.83 & 144.33 & 426.00 & 86.33 & 723.50 \\
\hline $\begin{array}{l}\text { Predicted events } \\
(2016-2035)\end{array}$ & 68.18 & 150.36 & 529.40 & 90.51 & 838.45 \\
\hline $\begin{array}{l}\text { Percentage change in } \\
\text { events }\end{array}$ & 2.01 & 4.17 & 24.27 & 4.84 & 15.89 \\
\hline \multicolumn{6}{|c|}{ Projected changes in fire events in central-south of Italy } \\
\hline $\begin{array}{l}\text { Average events } \\
(2000-2005)\end{array}$ & 61.17 & 197.00 & 1021.67 & 236.50 & 1516.33 \\
\hline $\begin{array}{l}\text { Predicted events } \\
\text { (2016-2035) }\end{array}$ & 63.01 & 226.87 & 1327.69 & 281.38 & 1898.95 \\
\hline $\begin{array}{l}\text { Percentage change in } \\
\text { events }\end{array}$ & 3.01 & 15.16 & 29.95 & 18.98 & 25.23 \\
\hline \multicolumn{6}{|c|}{ Projected changes in fire events in southern Italy } \\
\hline $\begin{array}{l}\text { Average events } \\
(2000-2005)\end{array}$ & 39.33 & 212.17 & 2835.00 & 653.17 & 3739.67 \\
\hline $\begin{array}{l}\text { Predicted events } \\
\text { (2016-2035) }\end{array}$ & 42.19 & 237.11 & 3021.58 & 780.35 & 4081.23 \\
\hline $\begin{array}{l}\text { Percentage change in } \\
\text { events }\end{array}$ & 7.25 & 11.75 & 6.58 & 19.47 & 9.13 \\
\hline
\end{tabular}


Table 12 continued

$$
\text { Winter (DJF) } \quad \text { Spring (MOM) } \quad \text { Summer (JJA) } \quad \text { Autumn (SON) } \quad \text { Annual }
$$

Panel B: Projected effects of climate change on area burnt in each geographical cluster

Projected changes in area burnt in northern Italy

\begin{tabular}{|c|c|c|c|c|c|}
\hline $\begin{array}{l}\text { Average area burnt } \\
(2000-2005)\end{array}$ & 4363.01 & 3594.47 & 1550.21 & 1115.15 & $10,622.84$ \\
\hline $\begin{array}{l}\text { Predicted area burnt } \\
(2016-2035)\end{array}$ & 5013.62 & 4757.05 & 2108.49 & 1195.54 & $13,074.70$ \\
\hline $\begin{array}{l}\text { Percentage change in } \\
\text { area burnt }\end{array}$ & 14.91 & 32.34 & 36.01 & 7.21 & 23.08 \\
\hline \multicolumn{6}{|c|}{ Projected changes in area burnt in central-north of Italy } \\
\hline $\begin{array}{l}\text { Average area burnt } \\
(2000-2005)\end{array}$ & 378.20 & 506.55 & 2042.57 & 327.19 & 3254.50 \\
\hline $\begin{array}{l}\text { Predicted area burnt } \\
(2016-2035)\end{array}$ & 388.91 & 531.82 & 3113.07 & 344.49 & 4378.29 \\
\hline Percentage change in & 2.83 & 4.99 & 52.41 & 5.29 & 34.53 \\
\hline
\end{tabular}

area burnt

Projected changes in area burnt in central-south of Italy

\begin{tabular}{|c|c|c|c|c|c|}
\hline $\begin{array}{l}\text { Average area burnt } \\
(2000-2005)\end{array}$ & 177.56 & 723.94 & 9598.40 & 1619.57 & $12,119.48$ \\
\hline $\begin{array}{l}\text { Predicted area burnt } \\
\quad(2016-2035)\end{array}$ & 186.12 & 843.12 & $17,855.19$ & 2278.14 & $21,162.57$ \\
\hline $\begin{array}{l}\text { Percentage change in } \\
\text { area burnt }\end{array}$ & 4.82 & 16.46 & 86.02 & 40.66 & 74.62 \\
\hline \multicolumn{6}{|c|}{ Projected changes in area burnt in southern Italy } \\
\hline $\begin{array}{l}\text { Average area burnt } \\
(2000-2005)\end{array}$ & 156.66 & 1539.71 & $39,805.69$ & 4209.28 & $45,711.33$ \\
\hline $\begin{array}{l}\text { Predicted area burnt } \\
\quad(2016-2035)\end{array}$ & 176.17 & 1833.09 & $48,264.41$ & 7218.28 & $57,491.96$ \\
\hline $\begin{array}{l}\text { Percentage change in } \\
\text { area burnt }\end{array}$ & 12.46 & 19.05 & 21.25 & 71.48 & 25.77 \\
\hline
\end{tabular}

All projected changes are obtained by using the significant estimates from Tables 6 and 7 for each geographic cluster for the fire events and area burnt, respectively. In this scenario, the projected mean temperature and precipitation levels for the spring (MON) and autumn (SON) are considered to be the average of projected mean temperature and precipitation levels for the winter (DJF) and summer (JJA) periods for each respective geographical cluster

\section{References}

Ascoli D, Bovio G (2013) Prescribed burning in Italy: a review of issues, advances and challenges. iForest 6:79-89

Bajocco S, Ricotta C (2008) Evidence of selective burning in Sardinia (Italy): which land cover classes do wildfires prefer? Landsc Ecol 23:241-248

Baltagi BH (2008) Econometric analysis of panel data, 4th edn. Wiley, West Sussex

Bedia J, Herrera S, San-Martín D, Koutsias N, Gutiérrez JM (2013) Robust projections of Fire Weather Index in the Mediterranean using statistical downscaling. Clim Change 120:229-247

Bedia J, Herrera S, Gutierrez J, Benali A, Brands S, Mota B, Moreno J (2015) Global patterns in the sensitivity of burned area to fire-weather: implications for climate change. Agric For Meteorol 214-215:369-379

Bernetti G (2005) Atlante di selvicoltura, selvicoltura edn. Ed Agricole, Bologna 
Blasi C, Boitani L, La Posta S, Manes F, Marchetti M (2005) Stato della biodiversità in Italia - Contributo alla strategia nazionale per la biodiversità. Palombi Editori

Bovio G, Marchetti M, Tonarelli L, Salis M, Vacchiano G, Lovreglio R, Elia M, Fiorucci P, Ascoli D (2017) Gli incendi boschivi stanno cambiando: cambiamo le strategie per governarli. Forest@ 14:202-205. https:// doi.org/10.3832/efor2537-014

Catry FX, Damasceno P, Silva JS, Galante M, Moreira F (2007) Spatial distribution patterns of wildfire ignitions in Portugal. In: Proceedings of the 4th international wildland fire conference, Seville

Coady D, Dizioli A (2018) Income inequality and education revisited: persistence, endogeneity and heterogeneity. Appl Econ 50:2747-2761

Costa L, Thonicke K, Poulter B, Badeck F-W (2011) Sensitivity of Portuguese forest fires to climatic, human and landscape variables: subnational differences between fire drivers in extreme fire years and decadal averages. Reg Environ Change 11:543-551

Crespo Cuaresma J, Havettová M, Lábaj M (2013) Income convergence prospects in Europe: assessing the role of human capital dynamics. Econ Syst 37:493-507

de Torres Curth M, Biscayart C, Ghermandi L, Pfister G (2012) Wildland-urban interface fires and socioeconomic conditions: a case study of a Northwestern Patagonia city. Environ Manag 49:876-891

Dimitrakopoulos AP, Vlahou M, Anagnostopoulou ChG, Mitsopoulos ID (2011) Impact of drought on wildland fires in Greece: implications of climatic change? Clim Change 109:331-347

Esposito S, Beltrano MC, De Natale F, Di Giuseppe E, Iafrate L, Libertà A, Parisse B, Scaglione M (2015) Atlante italiano del clima e dei cambiamenti climatici. Consiglio per la ricerca in agricoltura e l'analisi dell'economia agraria, Unità di ricerca per la climatologia e la meteorologia applicate all'agricoltura. Rome

Fernandes P, Luz A, Loureiro C (2010) Changes in wildfire severity from maritime pine woodland to contiguous forest types in the mountain of northwestern Portugal. For Ecol Manag 260:883-892

Ganteaume A, Camia A, Jappiot M, San-Miguel-Ayanz J, Long-Fournel M, Lampin C (2013) A review of the main driving factors of forest fire ignition over Europe. Environ Manag 51:651-662

Glaeser E, La Porta R, Shleifer A (2004) Do institutions cause growth? J Econ Growth 9(4):271-303

Gonzalez-Olabarria JR, Pukkala T (2011) Integrating fire risk considerations in landscape-level forest planning. For Ecol Manag 261:278-287

Hargrave J, Kis-Katos K (2013) Economic causes of deforestation in the brazilian amazon: a panel data analysis for the 2000s. Environ Resour Econ 54(4):471-494

IPCC (2013) Near-term climate change: projections and predictability (Chapter 11). In: Stocker TF, Qin D, Plattner G-K, Tignor M, Allen SK, Boschung J, Nauels A, Xia Y, Bex V, Midgley PM (eds) Climate change 2013: the physical science basis. Contribution of working Group I to the fifth assessment report of the intergovernmental panel on climate change. Cambridge University Press, Cambridge

Jolly MW, Cochrane MA, Freeborn PH, Holden ZA, Brown TJ, Williamson GJ, Bowman DMJS (2015) Climate-induced variations in global wildfire danger from 1979 to 2013. Nat Commun 6:7537. https:// www.nature.com/articles/ncomms 8537

Kousky C, Olmstead S (2010) Induced development in risky locations: fire suppression and land use in the America West, Working paper. Resources for the future, Washington, DC

Koutsias N, Arianoutsou M, Kallimanis AS, Mallinis G, Halley JM, Dimopoulos P (2012) Where did the fires burn in Peloponnisos, Greece the summer of 2007? Evidence for a synergy of fuel and weather. Agric For Meteorol 156:41-53

Koutsias N, Xanthopoulos G, Founda D, Xystrakis F, Nioti F, Pleniou M, Mallinis G, Arianoutsou M (2013) On the relationships between forest fires and weather conditions in Greece from long-term national observations (1894-2010). Int J Wildland Fire 22:493-507

Lasslop G, Hantson S, Kloster S (2015) Influence of wind speed on the global variability of burned fraction: a global fire model's perspective. Int J Wildland Fire 24:989-1000

Leone V, Lovreglio R, Martinez-Fernandez J (2002) Forest fires and anthropic influences: a study case (Gargano National Park, Italy). In: Viegas X (ed) Forest fire research and wild-land fire safety. Mill Press, Rotterdam, pp 11-28

Littell JS, Peterson DL, Riley KL, Liu Y, Luce CHA (2016) A review of the relationships between drought and forest fire in the United States. Global Change Biol 22:2353-2369

Lloret F, Calvo E, Pons X, Diaz-Delgado R (2002) Wildfires and landscape patterns in the Eastern Iberian Peninsula. Landsc Ecol 23:745-759

Martinez J, Vega-Garcia C, Chuvieco E (2009) Human-caused wildfire risk rating for prevention planning in Spain. J Environ Manage 90:1241-1252

Miranda AI, Marchi E, Ferretti M, Millan M (2008) Forest Fires and Air Quality Issues in Southern Europe. In: Bytnerowicz A, Arbaugh M, Andersen C, Riebau A (eds) Wildland fires and air pollution. Elsevier series "Developments in Environmental Science 8", Elsevier, Amsterdam 
Moreira F, Vaz P, Catry F, Silva JS (2009) Regional variations in wildfire susceptibility of land-cover types in Portugal: implications for landscape management to minimize fire hazard. Int J Wildland Fire 18:563-574

Moriondo M, Good P, Durao R, Bindi M, Giannakopoulos C, Corte-Real J (2006) Potential impact of climate change on fire risk in the Mediterranean area. Clim Res 31:85-95

Morita T et al (2001) Special report on emissions scenarios, 2.5.1.1 IPCC emissions scenarios and the SRES process. In: IPCC TAR WG3 2001

Naveh Z (1995) Interaction of landscapes and cultures. Landsc Urban Plan 32:43-54

Pausas JG (2004) Changes in fire and climate in the eastern Iberian Peninsula (Mediterranean basin). Clim Change 63(3):337-350

Pausas JG, Bradstock RA (2007) Plant persistence fire traits along a productivity and disturbance gradient in Mediterranean shrublands of SE Australia. Global Ecol Biogeogr 16:330-340

Pausas JG, Fernández-Muñoz S (2012) Fire regime changes in the Western Mediterranean Basin: from fuellimited to drought-driven fire regime. Clim Change 110:215-226

Pausas JG, Paula S (2012) Fuel shapes the fire-climate relationship: evidence from Mediterranean ecosystems. Glob Ecol Biogeogr 21(11):1074-1082

Pausas JG, Llovet J, Rodrigo A, Vallejo R (2008) Are wildfires a disaster in the Mediterranean Basin? A review. Int J Wildland Fire 17(6):713-723

Pazienza P, Beraldo S (2004) Adverse effects and responsibility of environmental policy: the case of forest fires. Corp Soc Responsib Environ Manag 11:222-231

Preisler HK, Brillinger DR, Burgan RE, Benoit JW (2004) Probability based models for estimating wildfire risk. Int J Wildland Fire 13:133-142

Prestemon JP, Butry DT (2005) Time to burn: modelling wildland arson as an autoregressive crime function. Am J Agric Econ 87:756-770

Prestemon JP, Pye JM, Butry DT, Holmes TP, Mercer DE (2002) Understanding broadscale wildfire risks in a human dominated landscape. For Sci 48:685-693

Reetz SWH, Brummer B (2011) Determinants of land use change dynamics in the margins of protected forest areas: evidence from Central Sulawesi, Indonesia, 2011 International Congress, August 30-September 2, 2011, Zurich, Switzerland

Rego FC, Silva JS (2014) Wildfires and landscape dynamics in Portugal: a regional assessment and global implications. In: Azevedo JC, Perera AH, Pinto AM (eds) Forest landscapes and global change: challenges for research and management. Springer, New York, pp 51-73

Ricotta C, Guglietta D, Migliozzi A (2012) No evidence of increased fire risk due to agricultural land abandonment in Sardinia (Italy). Nat Hazards Earth Syst Sci 12:1333-1336

Rodríguez y Silva F, Molina JR, González-Cabán A, Herrera Machuca MA (2012) Economic vulnerability of timber resources to forest fires. J Environ Manage 100:16-21

Salis M, Ager AA, Finney MA, Arca B, Spano D (2014) Analyzing spatiotemporal changes in wildfire regime and exposure across a Mediterranean fire-prone area. Nat Hazards 71(3):1389-1418

San-Miguel-Ayanz J, Durrant T, Boca R, Libert G, Branco A, de Rigo D, Ferrari D, Maianti P, Artés Vivancos T, Schulte E, Loffler P (2017) Forest fires in Europe, Middle East and North Africa 2016. EUR 28707 EN, Publications Office, Luxembourg. ISBN 978-92-79-71292-0. https://doi.org/10.2760/17690

Telesca L, Lasaponara R (2006) Emergence of temporal regimes in fire sequences. Phys A 360:543-547

Telesca L, Amatulli G, Lasaponara R, Lovallo M, Santulli A (2005) Time-scaling properties in forest fire sequences observed in Gargano area (southern Italy). Ecol Model 185:531-544

Vadrevu KP, Eaturu A, Badarinath KVS (2006) Spatial distribution of forest fires and controlling factors in Andhra Pradesh, India using Spot Satellite Datasets. Environ Monit Assess 123:75-96

Van Wagner CE, Pickett TL (1987). Equations and Fortran program for the Canadian Forest Fire Weather Index System. Canadian Forestry Service, Forestry Technical Report 33, Ottawa

Vasilakos C, Kalabokidis K, Hatzopoulos J, Matsinos J (2009) Identifying wildland fire ignition factors through sensitivity analysis of a neural network. Nat Hazards 50(1):125-143

Wastl C, Schunk C, Leuchner M, Pezzatti GB, Menzel A (2012) Recent climate change: long-term trends in meteorological forest fire danger in the Alps. Agric For Meteorol 162-163:1-13

Westerling AL, Hidalgo HG, Cayan DR, Swetnam TW (2006) Warming and earlier spring increase western US forest wildfire activity. Science 313:940-943

Wotton BM, Martell DL, Logan KA (2003) Climate change and people caused forest fire occurrence in Ontario. Clim Change 60:275-295

Zumbrunnen T, Bugmann H, Conedera M, Burgi M (2009) Linking forest fire regimes and climate—a historical analysis in a dry inner Alpine Valley. Ecosystems 12:73-86 